\title{
Spatial-Temporal Variability of Droughts during Two Cropping Seasons in Sri Lanka and Its Possible Mechanisms
}

\author{
Sherly Shelton ${ }^{1,2,3} \cdot$ Faustin Katchele Ogou ${ }^{2,4} \cdot$ Buddhi Pushpawela $^{5}$ \\ Received: 7 June 2020 / Revised: 26 March 2021 / Accepted: 28 March 2021 / Published online: 17 May 2021 \\ (C) This is a U.S. government work and not under copyright protection in the U.S.; foreign copyright protection may apply 2021
}

\begin{abstract}
Drought management in Sri Lanka is mostly limited to relief provision due to the shortage of scientific details to develop sufficient drought risk management. Therefore, spatio-temporal variability of droughts in two cropping seasons, Yala (MayAugust) and Maha (October-March) in Sri Lanka, have been investigated using the Standardized Precipitation Evapotranspiration Index (SPEI). The SPEI-4 at August (SPEI-4 August $_{\text {) }}$ shows an apparent decadal variation over wet, intermediate, and dry climate regions in the country, which is coherent with the decadal shift of rainfall in 1999. For the Yala season, the number of drought events (SPEI-4 $4_{\text {August }}<-1$ ) in the late period (2000-2015) is higher than that in the early period (1985-1999). On the other hand, the decadal variation of SPEI- $6_{\text {March }}$ is not distinguished; however, the number of drought events (SPEI$\left.6_{\text {March }}<-1\right)$ in all climate regions is less after 2003 as compared to the early period. The principle component time series of SPEI$4_{\text {August }}$ and rainfall in Yala seasons $(r=0.93)$ have closely associated, which implies that rainfall received in the Yala season can ascribe the observed decadal variation in SPEI- $4_{\text {August }}$. In the Yala season, less moisture transport towards Sri Lanka is observed in the late period due to the weakening of $850 \mathrm{hPa}$ wind circulation and increasing of $500 \mathrm{hPa}$ geopotential height, which causes more moisture divergence and ultimately affects the decreasing rainfall over the country. Meanwhile, the observed rainfall variability in cropping seasons, especially in the Yala season, is characterized by the large-scale circulation at interannual (Nino3.4) to decadal-scale (Pacific Decadal Oscillation (PDO), and North Atlantic Oscillation (NAO).
\end{abstract}

Keywords SPEI, Yala and Maha seasons · Drought variability $\cdot$ Decadal shift of rainfall $\cdot$ Large-scale circulation indices

\section{Introduction}

Changes in the global climate alter the hydrological cycle (Rosmann et al. 2016; Back et al. 2013). As a result, changes in extreme climate events frequently occur with greater severity

Responsible Editor: Jin-Ho Yoon.

Buddhi Pushpawela

buddhigp@caltech.edu

1 International Center for Climate and Environment Sciences (ICCES), Institute of Atmospheric Physics, Chinese Academy of Sciences, P.O. Box 9804, Beijing 100029, China

2 University of Chinese Academy of Sciences, Beijing 100049, China

3 Industrial Technology Institute, Colombo, Sri Lanka

4 Key Laboratory of Regional Climate-Environment for Temperate East Asia, Institute of Atmospheric Physics, Chinese Academy of Sciences, P.O. Box 9804, Beijing 100029, China

5 Division of Chemistry and Chemical Engineering, California Institute of Technology, Pasadena, CA, USA
(Polade et al. 2014; O'Gorman 2012; Sun et al. 2012; Seager et al. 2012). The extreme climate events, along with their associated disasters, can cause severe damage to crop yield and have the potential to destabilize food systems, threatening local to global food security (Lesk et al. 2016). Among these extreme climate events, drought is one of the more devastating natural hazards, affecting millions of people and causing extensive damage to crops and natural ecosystems in the world each year (Zhao and Li 2015). For instance, Food and Agriculture Organisation (FAO) estimated that hydrometeorological disasters such as floods and droughts caused $83 \%$ of losses in crop and livestock production in developing countries in 2003 and 2013 (FAO 2015). Furthermore, the severity of the economic impact of the drought is growing. Between 2005 and 2015, the average annual loss in crop and livestock production in developing countries had skyrocketed from under USD 2 billion per year until 2010 to approximately USD 8 billion in 2014 (FAO 2018). Notably, between 1900 and 2010, two billion people were affected, and more than ten million people passed away worldwide because of the impacts of drought (Van Loon 2015). 
Even though the drought has a massive impact on society, quantifying drought characteristics (intensity, magnitude, duration, and spatial extent), predicting and mitigating drought are difficult tasks among the climate community (VicenteSerrano et al. 2016). Droughts are considered to be the most complex and least-understood natural hazard, interrelated with many different processes such as land-based processes (e.g., precipitation, evaporation rates, soil moisture current, runoff (Spinoni et al. 2017; Dai 2011)), atmospheric processes (monsoon circulations, atmospheric evaporative demand) (VicenteSerrano et al. 2020; Zhang and Zhou 2015; Lin and Shelton 2020), and ocean processes (teleconnection with sea surface temperatures) (Dai 2011; Spinoni et al. 2017; Abiy et al. 2019). Due to its complexity, there is no acceptable universal approach to defining, monitoring, or quantifying drought characteristics, the spatial and temporal extent, up to date (Quiring 2009). To assess and clarify the characteristics of droughts, different drought indices have been developed in the last few decades, such as the Palmer Drought Severity Index (PDSI) (Palmer 1965), the Standardized Precipitation Index (SPI) (McKee et al. 1993), the Reconnaissance Drought Index (RDI) (Tsakiris 2004), and the Standardized Precipitation Evapotranspiration Index (SPEI) (VicenteSerrano et al. 2010). These indices are widely adopted in global and regional scale drought-related studies (Potop et al. 2012; Potopová et al. 2015; Yao et al. 2018). The recently developed SPEI is widely used to identify the drought impacts on hydrological, agricultural (Potop et al. 2012), and ecological systems. In addition, the SPEI is employed to explain the atmospheric drought mechanisms (Vicente-Serrano et al. 2011), analyzed drought variability (Potop et al. 2012), drought reconstruction (Allen et al. 2011). Furthermore, the SPEI is a more reliable indicator to identify drought characteristics such as drought severity (Beguería et al. 2014). Lin and Shelton (2020) have adopted the SPEI to describe the drought characteristics and variability in the Mahaweli River Basin of Sri Lanka and found that SPEI well reproduces the observed droughts during 1985-2015.

Droughts gradually initiate with a precipitation deficit and usually hit different regions of a country with varying levels of intensity and at different time scales. IPCC (2014) states that the tropics and subtropics recorded more intensified droughts with a longer time scale since the 1970s. For example, in the South Asian region, India, Pakistan, and Sri Lanka have experienced long-lasting droughts once every 3 years due to the Indian summer monsoon rainfall variability (Aadhar and Mishra 2017). In terms of the number of people affected, and the relief provided, drought had been regarded as one of the most significant climate hazards in Sri Lanka (Zubair et al. 2006). According to Disaster Management Centre - Sri Lanka (DMC) (http://www.desinventar.lk/), the number of people affected by drought has gradually increased from the year 2000 onwards; in particular, above $6 \%$ of the total population affected by drought in 1998, 2001, 2004, 2014, and 2017 (http://www.desinventar.lk/). In general, the prolonged drought, with high severity, severely hit the agriculture production as most of the cultivation in the intermediate and dry zones in Sri Lanka depends on the numerous irrigated or semi-rain fed minor reservoirs'. For example, the continued drought conditions from 2016 to 2017 declined the paddy production by $46 \%$, which is the lowest paddy production over the last decade in Sri Lanka (Central Bank 2017). In addition, Aadhar and Mishra (2017) found that more than 0.2 million people in South India and Sri Lanka have affected by the prevailing severe drought in 2017.

Despite many people affected by drought in the last few decades, few studies have focused on addressing the spatialtemporal variability of drought over Sri Lanka with recurrent drought conditions. For example, Lyon et al. 2009 assessed the potential use of meteorological drought indices as predictors of drought relief payments in Sri Lanka for 1960-2000. They found a statistically significant relationship between drought indicators and relief payments both temporarily and spatially in Sri Lanka, suggesting the potential utility of meteorological drought assessments for disaster risk management. The study conducted by Burchfield and Gilligan (2016) investigated the structural and dynamic factors of agricultural adaptation in response to severe drought in Sri Lanka in 2014. Their finding suggested that dynamic factors such as local autonomy, effective monitoring, perceived risk, diversification potential, community cohesion, and farmer experience affected agricultural adaptation more than structural factors. Gunda et al. (2016) used the PDSI and the SPI at a 9-month scale (SPI-9) to assess the spatial-temporal distribution of drought over Sri Lanka. They found that different indices correlated best with different climate zones in Sri Lanka. For example, PDSI correlated best with the intermediate zone, SPI-9 correlated best with the dry zone, but neither index correlated well with the wet zone. They also evaluated the potential impacts of drought on soil moisture regimes over the wet and dry zones.

However, these studies did not focus on investigating drought variation, and its associated mechanisms, in major cropping seasons (Yala and Maha seasons) in Sri Lanka. Gunda et al. (2016) recommended the need for further research to identify a drought index such as SPEI for evaluating the drought characteristics in wet and dry zones. Global Water Partnership - South Asia (GWP-SAS) also highlighted the importance of identifying the characterization of regional drought using appropriate drought index on seasonal time scales and for different climate regions in Sri Lanka (GWPSAS 2014). However, up-to-date drought variability during the Yala (May to August) and Maha (October to March) cropping seasons are not well studied by the previous researchers. In addition, most studies use simple SPI indices, 
which are only based on precipitation to identify drought characteristics, without incorporating the effect of potential evapotranspiration. Furthermore, the relationship between monsoon circulation and drought is not well established in Sri Lanka. Moreover, the influence of the variability of large-scale ocean circulation such as El Niño-Southern Oscillation (ENSO), Pacific Decadal Oscillation (PDO), and North Atlantic Oscillation (NAO) on rainfall during these two cropping seasons is not being investigated.

At present, drought management in Sri Lanka is primarily limited to relief provision; however, it is now recognized that risk management and ongoing adaptation are required due to the significant impact on crop yield and the livelihoods of people. Therefore, strong evidence-based scientific information is desirable to develop more effective disaster risk management and adaptation interventions. It is a vital step to secure the most vulnerable inhabitants in drought-affected areas and to ensure food security at a local level. Therefore, using the most updated data sets from more observational stations, this study focuses on bridging the research gap relevant to drought variability and its associated mechanisms during the major cropping seasons in Sri Lanka. The paper is organized as follows: section 1 presents the introduction with a background of drought in Sri-Lanka, section 2 describes the study site and the datasets, section 3 discusses the methodology adopted by this study, section 4 presents results and discussions, and section 5 summarizes the main findings.

\section{Study Site and Data}

\subsection{Study Site}

Sri Lanka is a tropical island country located off the Indian Ocean $\left(5^{\circ} 55^{\prime} \sim 9^{\circ} 51^{\prime} \mathrm{N}\right.$ and $79^{\circ} 41^{\prime} \sim 81^{\circ} 53^{\prime} \mathrm{E}$. The southwest (SWM, June to September) and northeast (NEM, December to February) monsoons are the two main monsoon seasons in Sri Lanka (Malmgren et al. 2003). In between dominant monsoon seasons, there are two inter-monsoonal periods called first inter-monsoon (FIM, March to May) and second intermonsoon (SIM, October to November). The southern and southwestern regions and the western side of the central mountains receive more rainfall during the SWM season (Wickramagamage 2016). The NEM season brings rain to the eastern part of the central highland, northern and eastern side of the island. Based on the regional differences in the rainfall amount, seasonality, and variability, the wet zone, intermediate zone, and the semiarid dry zone have been well-demarcated (Ranatunge et al. 2003; Rubasinghe et al. 2015; Malmgren et al. 2003; Lin and Shelton 2020) as shown in Fig. 1a. In the wet zone, peaks, ridges, basins, valleys, plateaus, and escarpments are dominant, while most of the dry and intermediate zones have flat terrain with few isolated hills. As a result of the complex topographic features, climatic elements such as rainfall, winds, temperature, relative humidity demonstrate significant differences among the three zones. For instance, the annual total rainfall in wet and intermediate dry zones is about $2500 \mathrm{~mm}$ and $1500 \mathrm{~mm}$, respectively (Rubasinghe et al. 2015). The mean annual average temperature of the $0-150 \mathrm{~m}$ is $27^{\circ} \mathrm{C}$, while it abruptly decreases as the altitude increases in the highlands. At an altitude of about $1800 \mathrm{~m}$, the mean annual temperature is $15^{\circ} \mathrm{C}$ (Marambe et al. 2014).

Based on the seasonal rainfall pattern in Sri Lanka, the two pronounced cropping seasons are known as Maha and Yala. The Maha cropping season starts from October to March, while the Yala cropping season begins in May spans up to the end of August (Marambe et al. 2014). During the Maha cropping season, rainfall receives mainly from the SIM and NEM. Sonnadara (2015) addressed that the dry region where most paddy fields are located gets adequate rainfall from these two monsoon seasons. The Yala cropping season is based on the SWM rainfall and is concentrated in the wet region, while relatively less rainfall is received over the intermediate and dry regions. Consequently, the irrigated water is the key water source for cultivation in the dry and intermediate regions. The wet zone receives rainfall mainly from the SWM and SIM seasons, while NEM and FIM season bring a significant amount of rainfall, sufficient for year-round farming (Jayawardene et al. 2005).

\subsection{Data Description}

The Department of Meteorology-Sri Lanka provides continuous monthly rainfall, minimum and maximum temperature data from 18 meteorological stations for the period 1985-2015. The spatial distribution of the meteorological stations is shown in Fig. 1a. The present study has used $1^{\circ}$ $\times 1^{\circ}$ resolution of the Sea surface temperature (SST) data (Rayner et al. 2003) from the Met Office Hadley Center Sea Ice and Sea Surface Temperature version 1.1(HadISST1.1) to calculate the Nino3.4 index for the study period. The NAO is defined as a meridional dipole in atmospheric pressure with centers of action near the Azores and Iceland (Xiao et al. 2015) and calculated using rotated principal component analysis. The NAO index is available at the Climate Prediction Center of the National Ocean and Atmospheric Administration (NOAA) (https://www.cpc.ncep.noaa.gov/products/precip/CWlink/ pna/nao.shtml). The PDO is referred to as a long-lived ElNiño like a Pacific climate variability pattern and defined as the leading principal component of monthly SST anomalies in the North Pacific Ocean, poleward of $20^{\circ} \mathrm{N}$ (Zhang et al. 1997). The PDO index is available at the Earth System Research Laboratory (ESRL) of NOAA (http://www.esrl.noaa.gov/psd/data/correlation/pdo.data). 

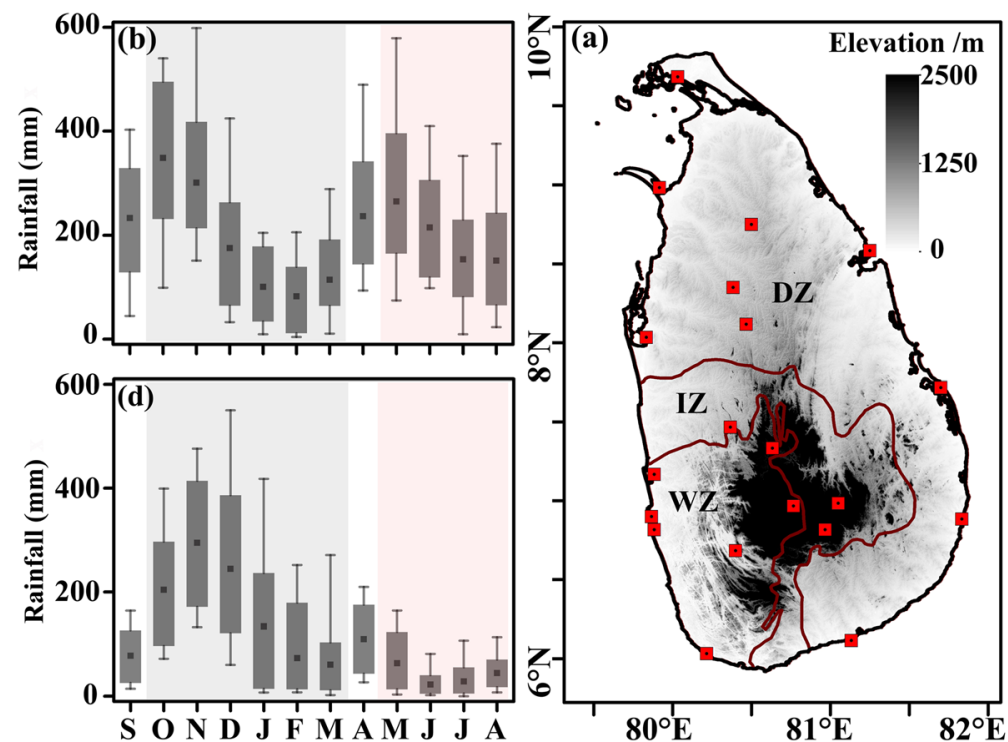

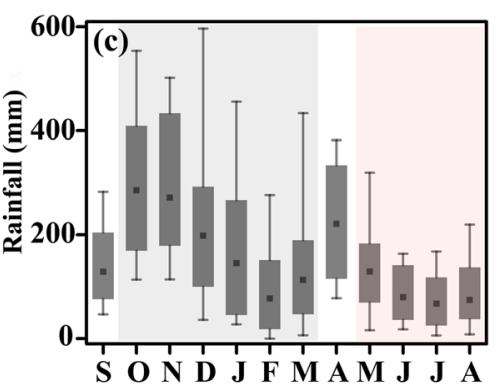

Fig. 1 The spatial distribution of meteorological station (red square) on (a) topography map of Sir Lanka and annual cycle of rainfall ( $\mathrm{mm} / \mathrm{month}$ ) for (b) wet, (c) intermediate, and (d) dry regions. The light ash and light pink strips indicate monthly groupings for the Maha (October-March) and Yala (May-August) seasons. The black dot indicates the long- term mean for monthly rainfall for the period 1985-2015. The lower and upper bounds in the box show $95^{\text {th }}$ and $10^{\text {th }}$ percentile rainfall, respectively. Whisker lines depict the maximum and minimum rainfall in each region
In addition to the observation data, the monthly $0.5^{\circ} \times 0$. $5^{\circ}$ grid resolution of the horizontal $(\mathrm{u})$, meridional $(\mathrm{v})$ wind at $850 \mathrm{hPa}$, and geo-potential height (z) at $500 \mathrm{hPa}$ from ERA-I (Dee et al. 2011) have been used to explain associated large scale mechanism. Global Precipitation Climatology Centre (GPCC) rainfall data set with $0.5^{\circ} \times$ $0.5^{\circ}$ grids resolution has been used to identify the spatial distribution of the rainfall during the Yala and Maha seasons over Sri Lanka.

\section{Methodology}

\subsection{Area Average Rainfall and Temperature}

Before calculating the SPEI, the area-weighted average precipitation and $\min / \max$ temperature time series have been considered for the three climate zones (wet, intermediate, and dry) previously defined (Malmgren et al. 2003; Ranatunge et al. 2003; Rubasinghe et al. 2015). Due to the complicated topographic features of Sri Lanka, the widely use Thiessen polygon (T.P.) method in hydrology and meteorology (Schumann 1998; Han and Bray 2006) cannot be used because it gives reliable rainfall estimation for flat terrain only. Therefore, the T.P. method with the elevation regression is applied to calculate area average rainfall in the three-climate zone. This method is previously used to estimate rainfall in the complex topographic watershed in Sri Lanka (Mahaweli River Basin) (Shelton and Lin 2019).

\subsection{Standardized Precipitation Evapotranspiration Index (SPEI)}

When considering the difference between SPI and SPEI, precipitation is the only meteorological parameter used for calculating the SPI, which can monitor both wet and dry conditions. It is well known that potential evapotranspiration contributes to drought and intensifies the severity (Dai 2011; Sheffield and Wood 2008; Sheffield et al. 2012). Interestingly, the SPEI index incorporates the potential evapotranspiration, which is intensified by increasing the average ocean and land temperature by $0.85^{\circ} \mathrm{C}$ during 1951-2012 (IPCC 2014). In this study, we also used SPEI to investigate drought variability in two cropping seasons in Sri Lanka.

The methods of calculating SPEI have been described by Vicente-Serrano et al. (2010) and can be calculated based on the difference between precipitation $(\mathrm{P})$ and potential evapotranspiration (PET), as shown in Eq. 1. Meanwhile, SPEI can be calculated at different timescales following Eqs. 2 and 3

$D=P-P E T$

$D_{i, j}^{k}=\sum_{l=j-k+1}^{j}\left(P_{\mathrm{i}, l}-P E T_{i, l}\right)$ if $j \geq k$

$D_{i, j}^{k}=\sum_{l=13-k+j}^{12}\left(P_{i-1, l}-P E T_{i-1, l}\right)+\sum_{l=1}^{j} P_{i, l}-P E T_{i, l} \quad$ if $j<k$

where $P$ and PET are monthly precipitation and potential evapotranspiration, $D$ represents the aggregated value of monthly precipitation minus potential evapotranspiration for 
$k$ timescale (months). $i$ (year) and $j$ (month) depend on the selected timescale $(k)$. In the next stage, we transformed $D_{i, j}^{k}$ into standardized units using a log-logistic probability distribution, and the standardized units to get the SPEI, which can be compared in space and time at different timescales (Vicente-Serrano et al. 2010).

For the drought analysis, the PET is vital for drought development and evolution, affected by temperature and other factors, like wind speed, humidity, sunshine duration or solar radiation, etc. In this study, the simplest Thornthwaite method (Thornthwaite 1948) has been used to calculate PET because most meteorological stations do not measure the climate parameters (wind speed, specific humidity, solar radiation, etc.) except rainfall and temperature. Mavromatis (2007) revealed that the calculated SPEI values are similar when using simple Thornthwaite and complex PET calculation methods to calculate PET. van der Schrier et al. (2011) suggested that this PET calculation method will not affect the observed variation of drought characteristics in the South Asian region. As further evidence, Lin and Shelton (2020) revealed that the method used for PET has not a strong influence on SPEI calculation for the Mahaweli River Basin in Sri Lanka.

Bärring et al. (2006) found a non-significant difference between the two results obtained using the observed area average with point observations for defining dry and wet spells. Therefore, area-averaged rainfall and temperature are used for calculating the SPEI index at 4- and 6-month time scales to represent the Yala and Maha cropping seasons, respectively. As Yala cropping season covers 4 months, i.e., May, June, July, and August, in order to consider the drought over this season, SPEI-4 at August (hereafter SPEI-4 $4_{\text {August }}$ is calculated, so rainfall and potential evapotranspiration from May to August can all be taken into consideration for deriving the SPEI- $4_{\text {August }}$. The Maha cropping season covers 6 months spanning from October to March; in order to represent the drought over this season, SPEI-6 at March (SPEI- $6_{\text {March }}$ ) was calculated using the rainfall and Evapotranspiration for October to March period.

According to the Central Bank reports, we firstly selected severe drought years and most wet years for both seasons separately to identify the spatial distribution of the SPEI6 March and SPEI-4 $4_{\text {August }}$. For the Maha season, 1994 is considered a wet year, while severe droughts were recorded in 2014 (Central Bank Report 1994 and 2014). The prevailing drought during the Yala season in 2012 severely hit economic growth due to the decline of agriculture production and a hydropower crisis in Sri Lanka (Central Bank Report 2012). Meanwhile, the whole country experienced extreme rainfall events during the Yala season in 1998 (Central BankReport 2012).

Furthermore, the SPEI- $6_{\text {March }}$ and SPEI- $4_{\text {August }}$ for every station in each region have been used to perform Empirical Orthogonal Functions (EOF) analysis to understand the spatial variability of droughts over Sri Lanka. If SPEI- $6_{\text {March }}<-1$ and SPEI- $4_{\text {August }}<-1$, we consider it as a drought event.

\subsection{Empirical Orthogonal Functions}

Different empirical techniques have been employed to investigate the variability of rainfall and droughts; among these techniques, EOF analysis is one of the widely adopted atmospheric science tools since the late 1940s. EOF compresses geophysical data fields in space and time, which denote orthogonal spatial patterns (eigenvectors) and the corresponding time series of Principal Component (PC). The EOF method separates the dominant mode of variability and decomposes data into spatial and temporal patterns. In general, the EOF technique is applied to find a new set of variables that capture most of the observed variance from the data through linear combinations of the original variables. The formulation and computation of EOFs are not described here because EOFs have been extensively studied in the literature (Hannachi et al. 2007; Navarra and Simoncini 2010) and widely used to identify the variability of drought in the different parts of the world (Wang et al. 2019; Kim et al. 2011; Wang et al. 2015). We applied EOF decomposition towards the seasonal average variate field of SPEI (SPEI-4 4 August and SPEI- $6_{\text {March }}$ ), extracted the spatial modes and their corresponding time coefficients, and exposed the temporal and spatial variation of droughts in two cropping seasons.

The spatial variation of the SPEI- $4_{\text {August }}$, SPEI- $6_{\text {March }}$, and rainfall during the two seasons, the station based EOF analysis is performed and selected the first two Principal Component (PC1) time series. Based on the Student's t test, the correlation coefficients (r) for the PC1 of SPEI- $4_{\text {August }} /$ SPEI- $6_{\text {March }}$ and rainfall were tested for significance at a $95 \%$ confidence level.

To find out the step changes in PC1 of SPEI and rainfall anomalies, the distribution-free cumulative sum control chart (CUSUM) (Gocic and Trajkovic 2013), cumulative deviation, and Worsley likelihood ratio tests were used. If one out of those three tests detects the step change at $95 \%$ of lower confidence level, rank-sum test and student's $t$ test were used to assess the significance of differences between the mean for before and after the change.

\subsection{Cross-Wavelets Analysis}

Previous studies have focused on the teleconnection of largescale circulation indices and drought (Niranjan Kumar et al. 2013; Xiao et al. 2016; Torres-Valcárcel 2018; Wang et al. 2016; Wang et al. 2017). Among the large-scale circulation indices, the PDO and NAO are part of atmospheric circulation modes, while Nino3.4 represents the oceanic SST signal. We selected the PC1 time series of the Yala and Maha rainfall seasons and applied the cross wavelet transform (XWT) technique for identifying the relationship between rainfall in two 
cropping seasons and the aforementioned indices; because XWT can identify the regular variations occurring in a natural frequency with high accuracy in time scale (Grinsted et al. 2004). This technique is widely applied to examine oceanicclimatic fluctuations in most of the hydrometeorological studies (Deng et al. 2018; Echer et al. 2008; Grinsted et al. 2004).

\section{Results}

\subsection{Rainfall Distribution during the Two Cropping Seasons}

The rainfall pattern in Sri Lanka is heavy and seasonally well distributed due to the movement of the Inter-Tropical Convergence Zone (ITCZ) over the equatorial region (Burt and Weerasinghe 2014). Figures $1 \mathrm{~b}-\mathrm{d}$ show monthly rainfall distribution in wet, intermediate, and dry regions in Sri Lanka. The largest $(349.6 \mathrm{~mm})$ and lowest $(82.6 \mathrm{~mm})$ average monthly rainfall in wet is recorded in October and February, respectively. In the intermediate region, the largest average rainfall is recorded in October $(285.8 \mathrm{~mm})$. The lowest average rainfall in the intermediate region is $67.7 \mathrm{~mm}$ in July. In November, the dry region experiences the largest average rainfall $(294 \mathrm{~mm})$, and July is the driest month $(22.6 \mathrm{~mm})$. Based on the annual cycle in Fig. 1b-d, all the climate zones depict the bimodal distribution pattern of rainfall. For instance, the two rainfall peaks are observed in October and May in the wet region (Fig. 1b). Furthermore, the largest rainfall variation in the wet region is observed in May, while the other two regions exhibit considerable rainfall variation in December.

According to seasonal variation of rainfall, there are two monsoons (southwest and northeast) and two inter-monsoon (first inter-monsoon and second inter-monsoon) periods. During the
Yala cropping season, Southwest Monsoon rainfall (SWM-June to September) plays a key role. On the other hand, Maha cropping season consists of the second inter-monsoon (SIM; October-November) and Northeast Monsoon (NEM; December to February). In the wet region, the Maha (Yala) rainfall season contributes $52.2 \%(33.0 \%)$ of the total rainfall $(2382 \mathrm{~mm})$. The recorded annual total rainfall in the intermediate region is $1794.6 \mathrm{~mm}$, with $61.7 \%$ (19.5\%) of rainfall received during the Maha (Yala) season. The station-based area average total annual rainfall in the dry region is $1360 \mathrm{~mm}$, while $75.7 \%$ and $11 \%$ of rainfalls are received during the Maha and Yala seasons, respectively. The spatial distribution of rainfall during the Yala season is displayed in Fig. 2a where the wet region receives considerable rainfall during the May-August, and most of the dry and intermediate regions recorded the lowest rainfall due to the orographic influence of the central mountain. It is apparent that the whole country receives adequate rainfall during the SIM season (October and November) (Fig. 2b). The eastern part of the country gets more rainfall during the NEM season, as shown in (Fig. 2c).

Considering the spatial rainfall distribution, it is evident that the Maha rainfall is sufficient for agriculture production in the whole country; however, due to the less rainfall amount in the Yala season, the cropping in the intermediate and dry region mostly depends on irrigation. During the Yala season, most of the farmers in intermediate and dry regions cultivate selected crops, which need fewer water requirements for growth as the solution for water scarcity.

\subsection{Drought Variation in Two Cropping Seasons}

Based on the Central Bank reports, the spatial distribution of SPEI- $6_{\text {March }}$ and SPEI- $4_{\text {August }}$ in severe drought and most wet years are displayed in Fig. 3. As shown in Fig. 3a-b, whole
Fig. 2 The rainfall climatology (mm/month) for (a) May-August (MJJA), (b) October-November $(\mathrm{ON})$, and (c) DecemberFebruary (DJF) over Sri Lanka for the 1985-2015 period. Black lines demarcate the wet, intermediate, and dry climate zones

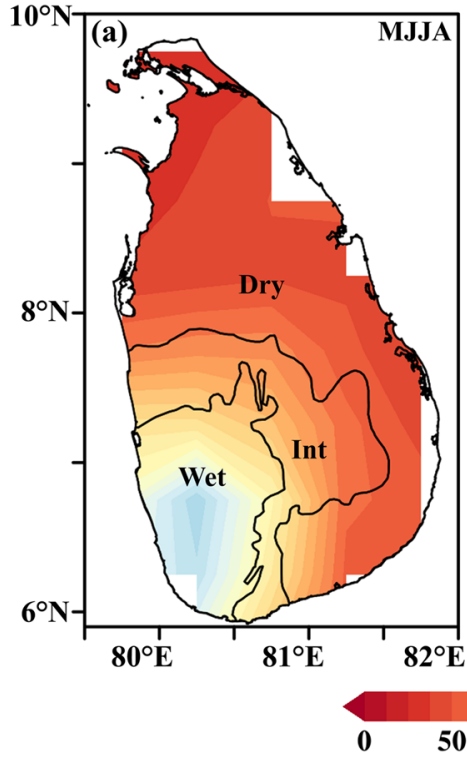

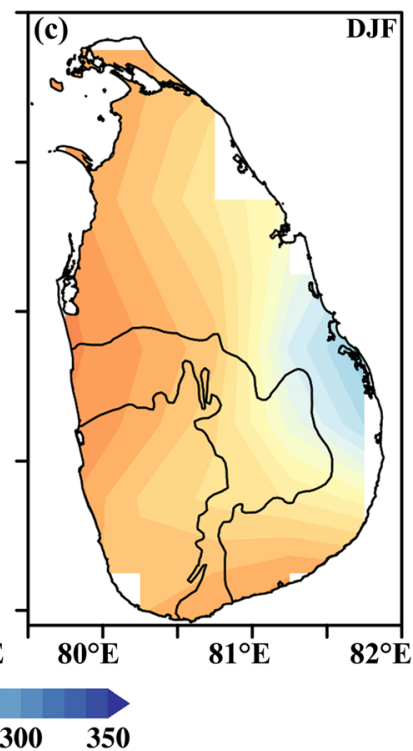




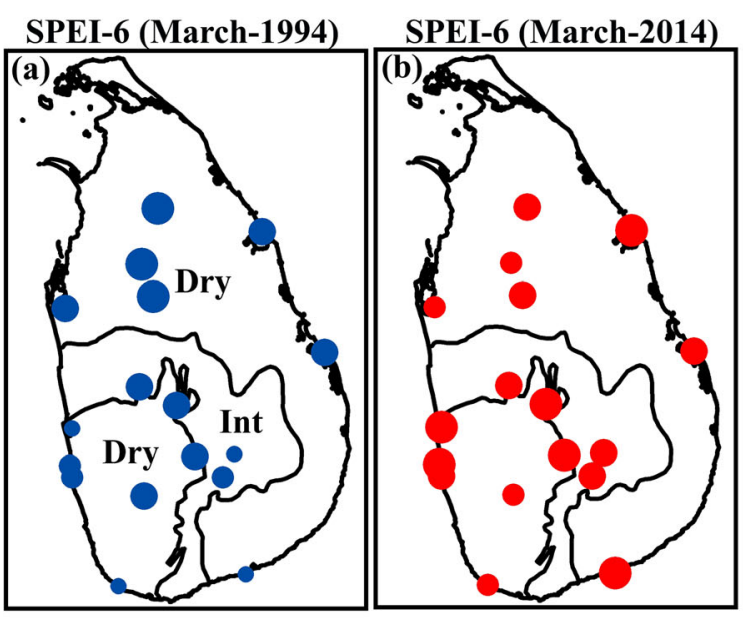

SPEI-4 (August-1998)

SPEI-4 (August-2012)
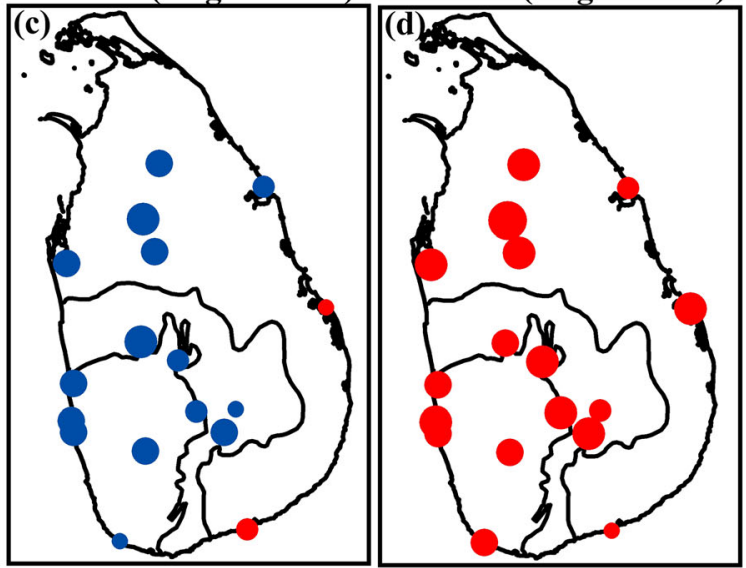

$-2<-2 \sim 1.5-1.5 \sim 1-1 \sim-0.5-0.5 \sim 0000.5 \quad 0.5 \sim 1-1 \sim 1.5-1.5 \sim 2 \sim 2<$

Fig. 3 Spatial distribution of SPEI-6 at March (SPEI- $6_{\text {March }}$ ) in relatively (a) wet (1994) and (b) dry (2014) Maha seasons in Sri Lanka. (c, d) are

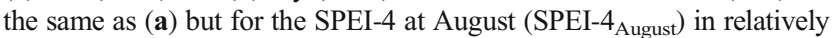
wet (1998), and dry (2012) Yala season, respectively. The specific years

stations showed a positive SPEI-6 $6_{\text {March }}$ in 1994 and negative SPEI- $6_{\text {March }}$ in 2014. When we take a close look at the distribution of SPEI- $6_{\text {March }}$, it is found that positive SPEI- $6_{\text {March }}$ is concentrated in the dry region $(1.5 \sim 2)$, while negative SPEI$6_{\text {March }}$ are more prominent in the western and southwestern part of the country (Fig. 3b). During the Yala season in 1998, all the stations attributed to positive SEPI- $4_{\text {August }}$, except two stations in the southeastern and eastern part of the country, suggested that the whole country experienced rainfall (Fig. $3 c)$. In contrast, negative SEPI- $4_{\text {August }}$ is recorded for all the stations during the Yala season in 2012 (Fig. 3d), where most of the station exceeds dought threshold limits (SEPI- $4_{\text {August }}<$ $-1)$. Based on these findings, it is suggested that the magnitude of SPEI- $6_{\text {March }} /$ SPEI- $4_{\text {August }}$ differs from region to region and season to season. Consequently, we performed spatial EOF analysis for SPEI- $6_{\text {March }}$ and SPEI- $4_{\text {August }}$ to identify the spatial variability during 1985-2015.

Understanding the variability in drought during the main cropping season is essential to identify the risk of food security on a national scale. In this study, SPEI- $6_{\text {March }}$ and SPEI$4_{\text {Auguest }}$ are selected to identify droughts in Maha and Yala seasons, respectively. The drought $\left(\right.$ SPEI- $\left.6_{\text {March }}<-1\right)$ during the Maha season is observed in 1987, 1989, 1992, 1997, 2004, 2014, over the wet region (Fig. 4a). In the intermediate zone, the years 1992, 1997, 2004, and 2014 recorded drought events (Fig. 4b). As shown in Fig. 4c, the droughts during the Maha season are recorded in 1988, 1989, 1997, and 2014 over the dry zone. We further noticed that the number of drought events for wet (2) and dry (1) regions for the 2000-2015 is less compared with that of 1985-1999 (Fig. 4a-c).

Figure $4 \mathrm{~d}-\mathrm{f}$ illustrate the temporal evolution of droughts $\left(\right.$ SPEI- $\left.4_{\text {August }}\right)$ in wet, intermediate, and dry zones during the are selected based on the Central Bank reports in Sri Lanka. Black lines demarcate the wet, intermediate, and dry climate zones. The negative SPEI $($ SPEI $<-1)$ indicates drought, while positive SPEI (SPEI $>1)$ represents the wet events

Yala season, respectively. The droughts in the Yala season of 1986, 2001, 2002, 2011, and 2012 have been recorded over the wet zone. On the other hand, 1994, 2001, 2004, and 2012 recorded droughts in the intermediate region. The six drought events are recorded during the Yala season in 1994, 2002, 2005, 2006, 2011, and 2014 over the dry zone. It is interesting to notice that occurrences of drought in the Yala season of the late period (2000-2015) are comparatively higher than the early period (1985-1999). Based on the 9-year running mean of SPEI$4_{\text {August }}$, the decadal variation of droughts in the Yala season is identified over the three-climate zone in Sri Lanka (Fig. 4d-f). Similar to our findings, Niranjan Kumar et al. (2013) also found a decadal variation of the monsoon drought in India.

\subsection{Spatial Distribution of Seasonal Drought by EOF Analysis}

Based on EOF analysis, the first three loading vectors and their corresponding principal component (PC) series for SPEI- $6_{\text {March }}$ time series in Maha and Yala (SPEI-4 $4_{\text {August }}$ ) seasons have been shown by Figs. 5 and 6, respectively. The first three factors explain $78.7 \%$ of the total variance of SPEI$6_{\text {March }}$. Therefore, the first three EOFs and their corresponding PCs have been a good indicator to identify the primary features of drought patterns in the Maha season. For the Maha season, EOF1 explains $65 \%$ of the total variance of SPEI$6_{\text {March }}$, which exhibits the evolution of dry/wet conditions and coherent drought all over Sri Lanka (Fig. 5a). Based on the EOF value and associated PC1 time series, it can be concluded that the whole country experiences drought (wet) conditions irrespective of the climate zones during the Maha season in dry (wet) years. Results further show that the drought 

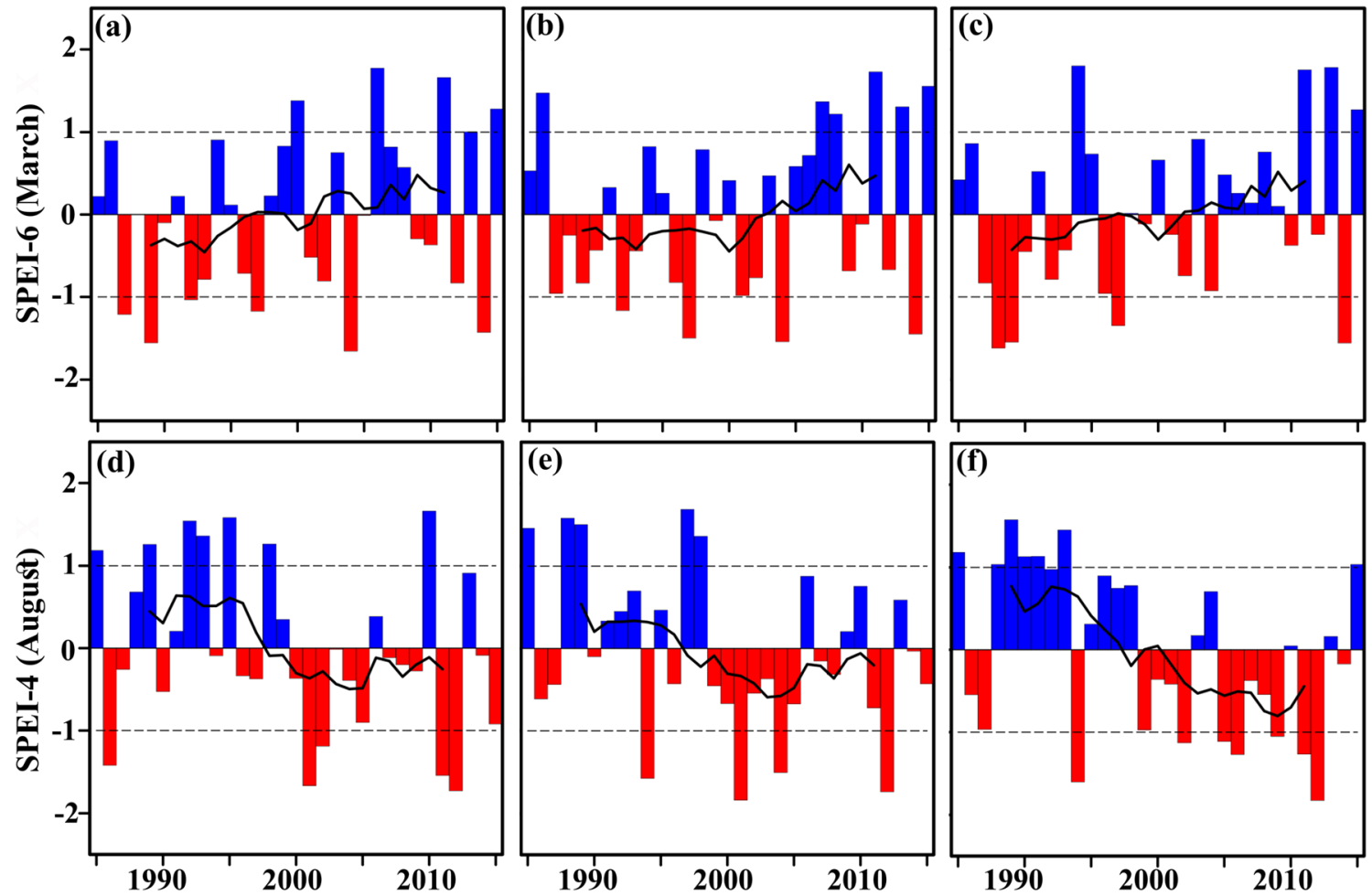

Fig. 4 Temporal evolution of SPEI-6 at March in (a) wet (b) intermediate and (c) dry climate zones in Sri Lanka for the period from 1985 to 2015. (d-f), are the same as top panels but for SPEI-4 at August. The thick black

line indicates the 9-year running mean, while the dashed lines indicate the +1 and -1 as a threshold for wet and dry events, respectively. The blue (red) bars represent positive (negative) values of the SPEI time series

events in the early (1985-1999) period were prominent compared to the late (2000-2015) period (Fig. 5a2). That suggests the climate was relatively dry before 1999 but became wet after 2000. The EOF2 accounted for $8.2 \%$ of the total variance (Fig. 5b1) and demonstrated dipole mode distribution over the wet and dry zones, including the intermediate zone in Sri Lanka. This type of distribution could be explained by the orographic influence and atmospheric circulation.

During the Maha season, the water vapor is mainly transported from the Bay of Bengal to the eastern and northeastern parts of Sri Lanka and then penetrates further to the western and northwestern parts of the country. However, due to the blocking effect of central mountains, which is situated in the central of the country (As shown in Fig. 1a), the moisture could not transport easily to the western and southwestern parts of the country. Hence, the rainfall and drought situation in the intermediate and dry regions are different from the wet regions during the Maha season.

The EOF and associated PC time series of drought during the Yala season is displayed in Fig. 6. EOF1 explained 44.2\% of the total variance. It reflects the evolution of wet and dry conditions over Sri Lanka. When EOF1 becomes positive from 1985 to 1999 , the whole country recorded wet conditions during the Yala period, but a contrast pattern is observed after 2000 (Fig. 6a2). The linear PC1 time series associated with a 9 -year running mean exhibited a decadal variation of drought during the Yala season. EOF2 explained $12.4 \%$ of the total variance of SPEI- $4_{\text {August }}$. Furthermore, it reflects the antiphase distribution of droughts over the wet and dry regions of the country (Fig. 6b1). Interestingly, the 9-year running mean of the PC time series related to EOF2 indicates the weak decadal variability signal in the Yala season (Fig. 6b2).

\subsection{The Rainfall Variation in the Two Cropping Seasons}

The PC1 time series of Yala and Maha rainfall is used to identify the relationship with the PC1 time series of SPEI$4_{\text {August }}$ and SPEI- $6_{\text {March }}$ (Fig. 7). Based on the EOF analysis, the three consecutive PCs of rainfall received in the Yala (Maha) season explained 53.2\% (59.2), 9.67\% (11.36), and $9.15 \%$ (6.86). On the one hand, the rainfall during the Maha season shows a strong relationship $(r=0.79)$ with SPEI- $6_{\text {March }}$ (Fig. 7a). On the other hand, the dominant mode of the SPEI$4_{\text {August }}$ has a statistically significant correlation $(r=0.93)$ with rainfall during the Yala season (Fig. $7 b$ ). Therefore, rainfall variation in Yala and Maha ascribed observed SPEI variation in two cropping seasons over three regions in Sri Lanka, indicating a weak effect of 4-6 months cumulative temperature variability on the seasonal precipitation variability over the period from 1985 to 2015, though the correlation of rainfall with SPEI-6 is higher than that with SPEI-4. 
Fig. 5 Empirical orthogonal function (EOF) analysis for SPEI6 at March (Maha season) for the period 1985-2015 (a1-b1) and their corresponding principal component (PC series (a2-b2). The thick black line indicates the 9-year running mean for the PC time series. The blue (red) bars represent a positive (negative) value of the PC time series
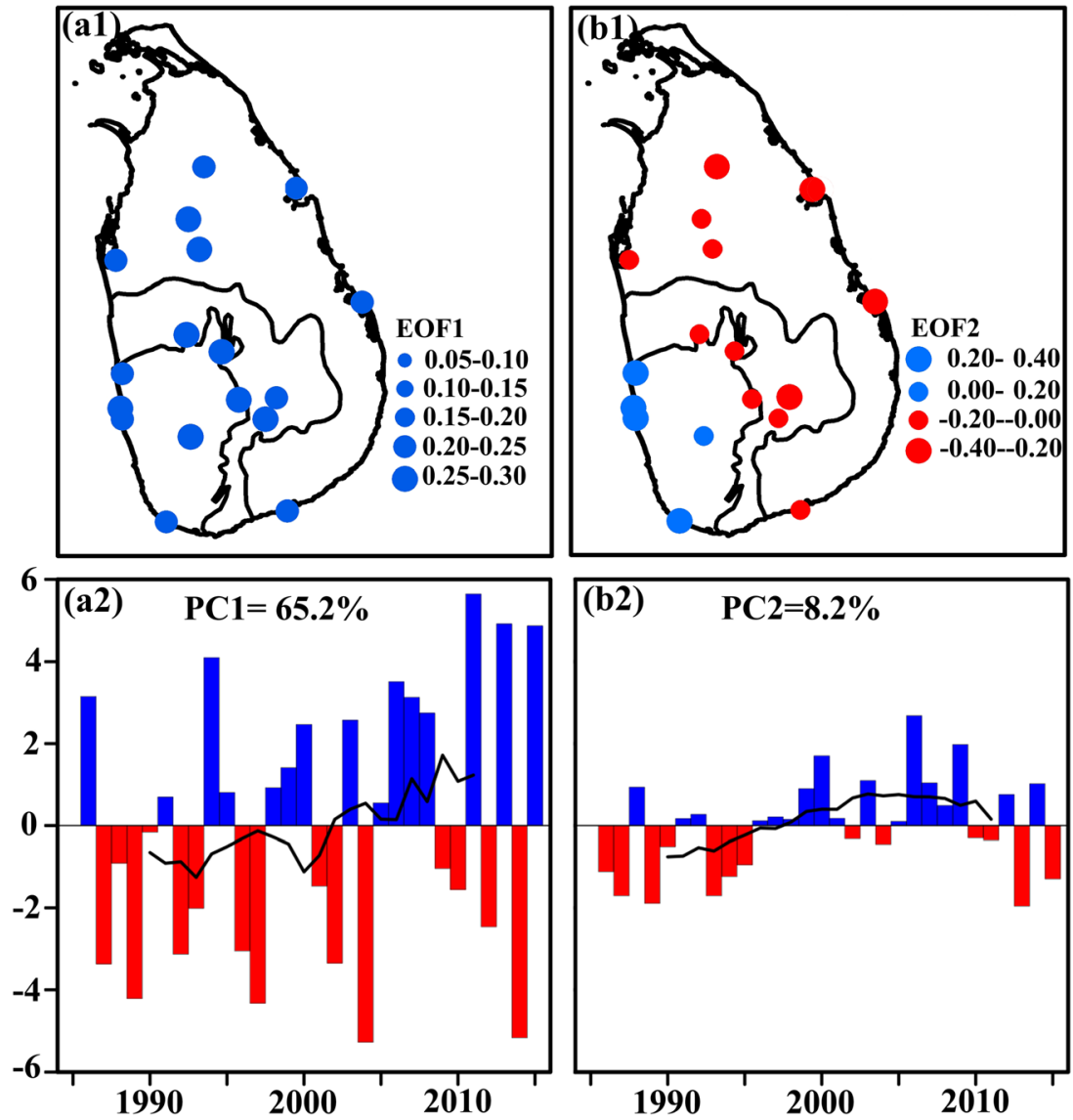

It can be suggested that both the timing and the spatial distribution of rainfall had an impact on drought evolution over a particular region (Deng et al. 2018). Therefore, the temporal variation of rainfall during the Maha and Yala seasons over three climate zones are investigated (Figs. 8a-f). Maha season falls within the second inter-monsoon (October-November) and Northeast monsoon (DecemberFebruary) season. The Yala season received rainfall mainly from the southwest monsoon (May-August) season. In the Maha season, the average monthly rainfall for the Wet, intermediate, and dry regions is 197,176 , and $159 \mathrm{~mm}$, respectively. The rainfall anomaly below the standard deviation $(-1 \sigma)$ is recorded in 1986, 1988, 1991, 2003, 2011, and 2013 for the wet region (Fig. 8a). Meanwhile, the years 1991, 1995, 1996, 2003, and 2013, are observed over the intermediate region, corresponding to the negative rainfall anomaly below the $-1 \sigma$ (45 $\mathrm{mm}$ ) (Fig. 8b). Notably, we found below-average rainfall events in 1987, 1988, 1991, 1996, and 2013 in the dry region (Fig. 8c). Based on the result, most of the negative rainfall anomalies during the Maha season are recorded in 1985-2000. The 9-year running mean indicates a weak decadal shift of the rainfall over the three regions during the study period.

The monthly average rainfall in the wet region $(196 \mathrm{~mm})$ is larger compared to the intermediate $(87 \mathrm{~mm})$ and dry $(39 \mathrm{~mm})$ regions during the Yala season. Negative rainfall anomalies below the $-1 \sigma$ (44 $\mathrm{mm}$ ) are recorded for 1986, 2000, 2001, 2011 and 2012 during the Yala season in the wet zone (Fig. 8d). As shown in Fig. 8e, the years 1994, 2001, 2002, 2004, 2011 , and 2012 were characterized by negative rainfall anomalies in the intermediate region, i.e., they are below the $-1 \sigma$ $(24 \mathrm{~mm})$ for the intermediate region. Figure $8 \mathrm{f}$ exhibits a negative rainfall anomaly during the Yala season in the years 1994, 1999, 2002, 2006, 2011, and 2012 for the dry zone. The results highlight that below-average rainfall events in the wet, intermediate, and dry regions are dominant in the late period (2000-2015) relative to the early period (1985-1999). For instance, we detected 12 negative anomalous rainfall years in wet and intermediate regions in the late period. The 9-year running mean emphasized a decadal rainfall shift during the early and late periods over three regions.

We applied abrupt change detection methods, namely the cumulative sum, cumulative deviation, and Worsley likelihood, to find the change points that have occurred during 1985-2015. Notably, a statistically significant change point of both Yala rainfall and SPEI-4 $4_{\text {August }}$ time series is observed in 1999. On the other hand, Maha rainfall showed a statistically non-significant change point in 1996; however, SPEI$6_{\text {March }}$ depicted a statistically significant change point in the year 2003 (Table 1). 
Fig. 6 Empirical orthogonal function (EOF) analysis for SPEI4 at August (Yala season) for the period 1985-2015 (a1-b1) and their corresponding principal component (PC series (a2-b2). The thick black line indicates the 9-year running mean for the PC time series. The blue (red) bars represent positive (negative) values of the $\mathrm{PC}$ time series
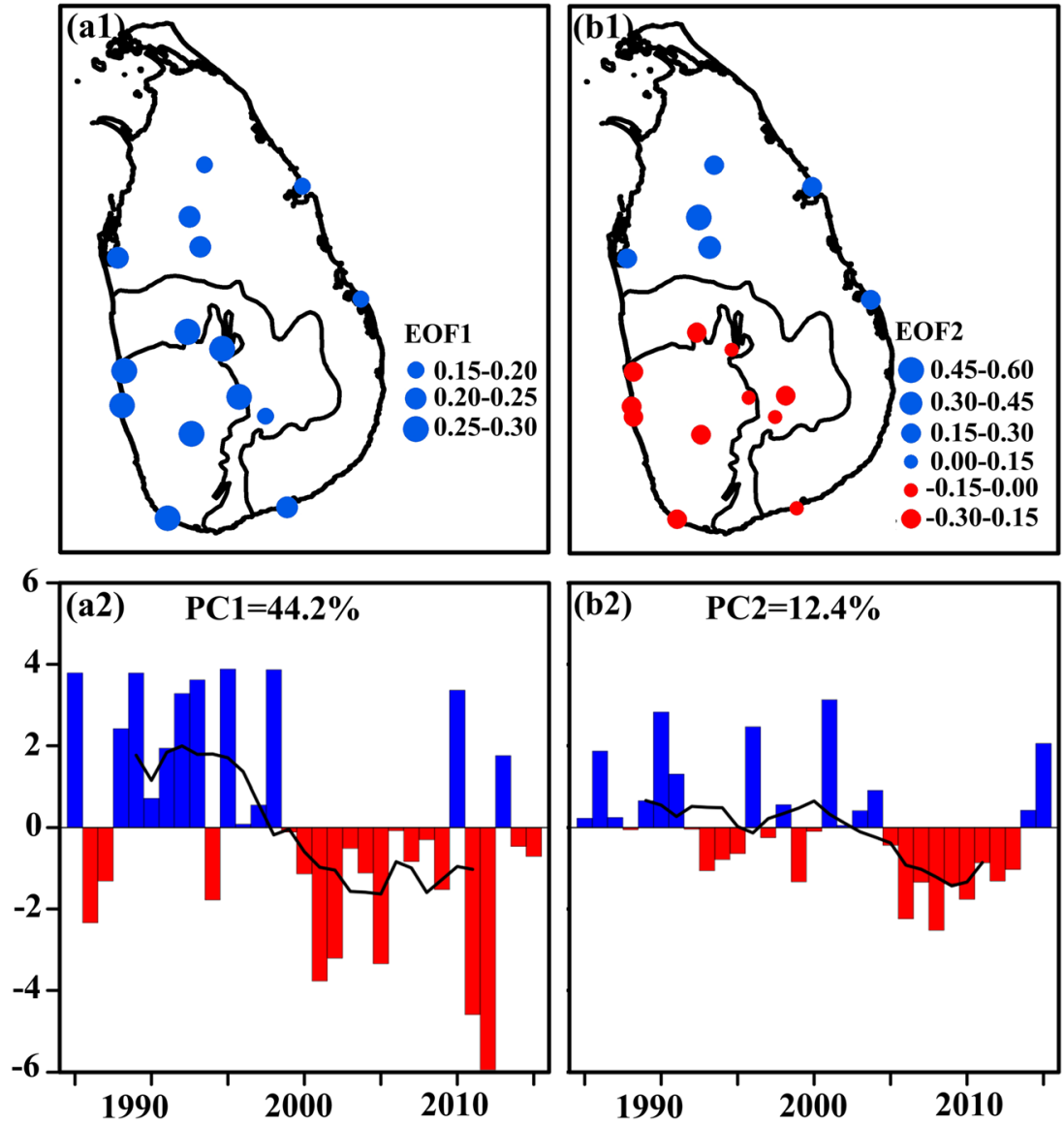

\subsection{The Influence of Large Scale Circulation on Seasonal Rainfall}

As we know, SSTs are warmer, and the trade winds are weaker than normal in the central and eastern Pacific Ocean, and
SSTs are cooler than normal in the eastern Indian and western Pacific Oceans during El Niño events. These conditions are reversed during La Niña events (Philander, 1990). El Niño and the Sothern Oscillation together comprise a complex atmosphere-ocean interaction system known as the ENSO
Fig. 7 The temporal evolution of the principal component one (PC1) time series of SPEI-6 at March (red line) and rainfall anomaly (blue line) for (a) Maha seasons (b) is the same as (a) but for the SPEI-4 at August (red line) Yala season. The correlation coefficient between PC1 of SPEI and rainfall anomaly is shown by $\mathrm{r}$, while the ** indicates a significant correlation at the $95 \%$ confidence level
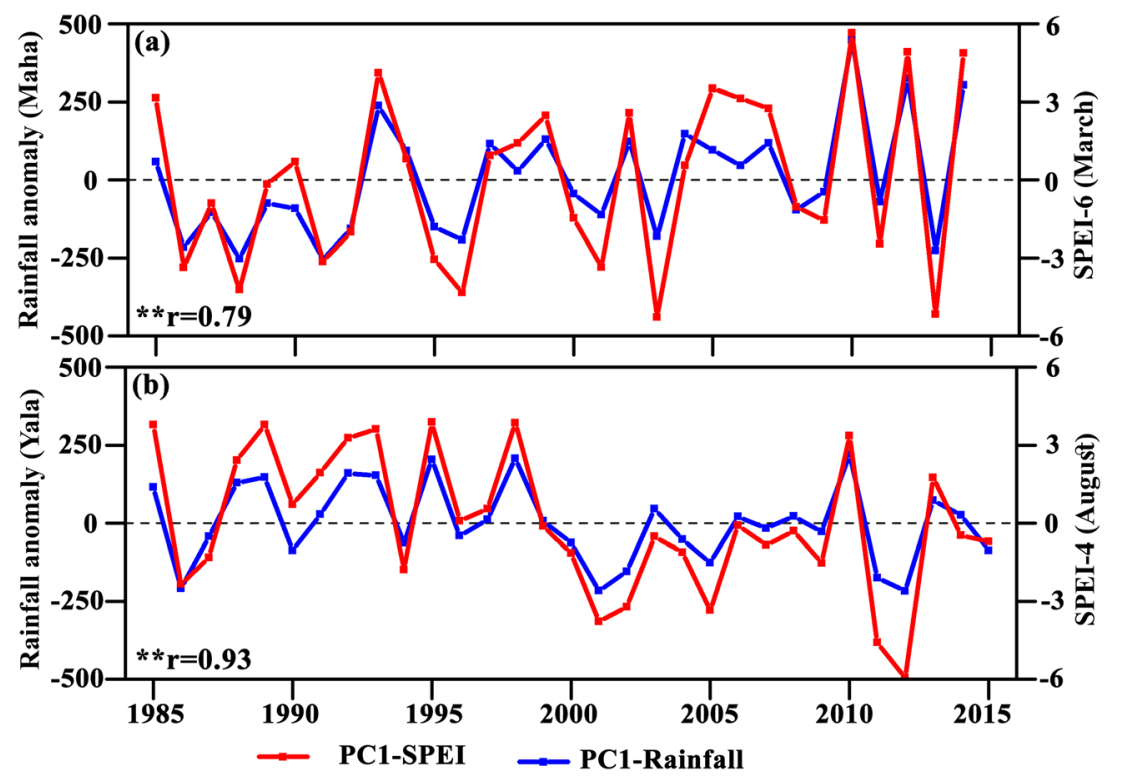
Fig. 8 Temporal evolution of rainfall anomaly (mm/month) for (a) wet, (b) intermediate, and (c) dry climate zones during the Maha season (October-March). (d-f), are the same as top panels but for the Yala Season (MayAugust). The thick black line indicates the 9-year running mean. The blue (red) bars represent positive (negative) rainfall anomalies. The $\mu$ and $\sigma$ represent the long-term mean ( $\mathrm{mm} / \mathrm{month})$ and standard deviation of rainfall, respectively, while the dashed horizontal lines indicate \pm standard deviations
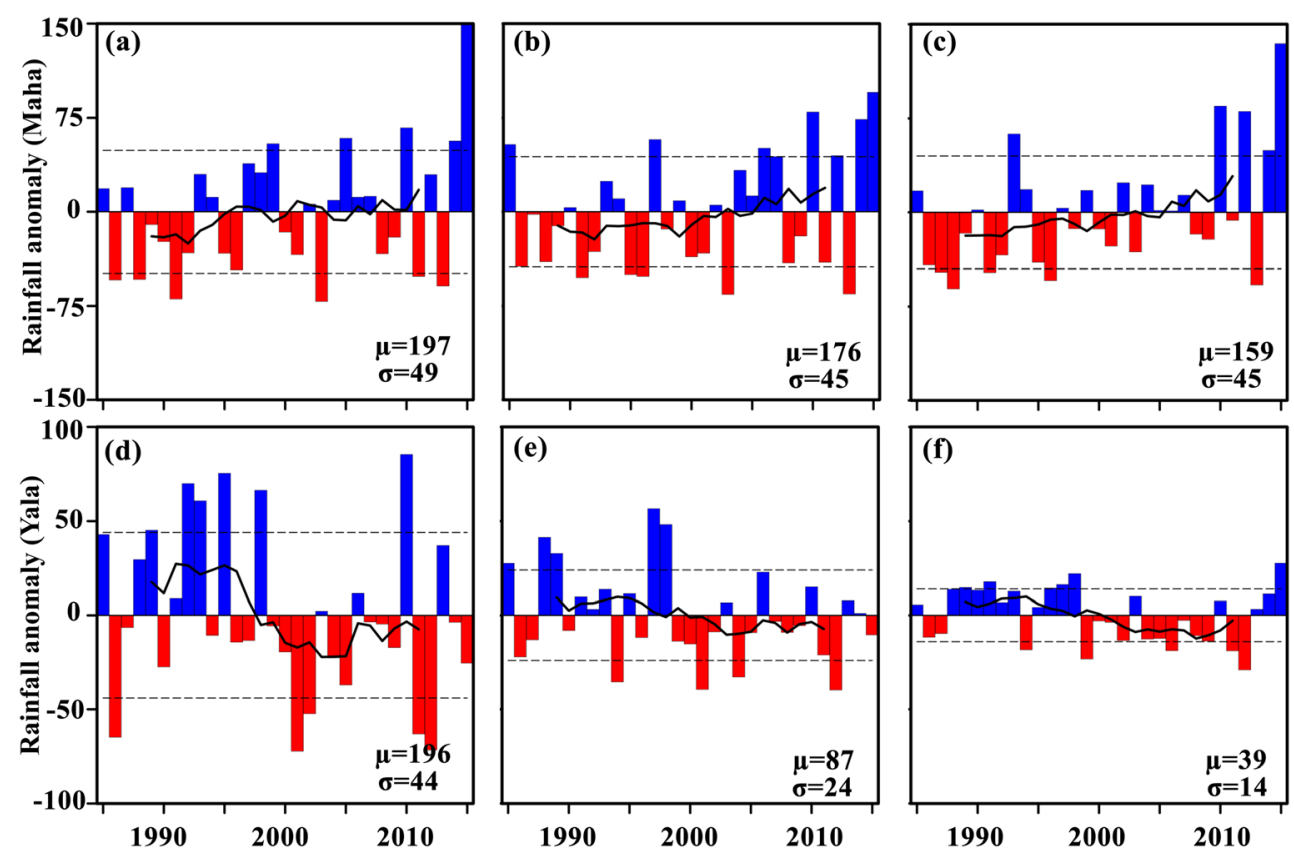

phenomenon. Shaman and Tziperman (2007) have depicted that ENSO-Indian Monsoon teleconnection comes from the ENSO related dynamics in the upper tropospheric midlatitude regions. Warming over the central Pacific creates upper tropospheric divergence over the region, which is the Rossby waves source. These Rossby waves are guided by North-African-Asian jet, and associated positive vorticity anomalies do get flooded over the central Asian regions. The effect of these anomalous positive vorticities is pronounced cooling over those regions, which resulted in weak temperature gradients in the upper troposphere over the Indian region. This disrupts the monsoon flow over the Indian region, and Sri Lanka experience below-average rainfall monsoon during ElNino years; in contrast, the inverse pattern is observed during the La-Nino years.

The previous study revealed that ISMR has negatively and strongly associated NAO with the previous spring (MAM), which might be explained in terms of the winter sea level pressure (SLP) over Azores High, one of the pressure centres of action in the NAO (Bhatla et al. 2016). It is observed below-average winter SLP over this reason, during the negative NAOI, which lead to weaker westerlies than usual carrying warm maritime air mass over the Eurasian region, as a result, increase the wintertime snow depth over Eurasia to enhance the good monsoon activity over the Indian region (Kripalani and Kulkarni 1999). However, the relationship between NAOI and ISMR changes its sign from negative to positive during monsoon season due to the intense westerlies with respect to the changing wind direction by more than 120 and increase in wind speed by at least by $3 \mathrm{~m} / \mathrm{s}$ in comparison to that of the pre-monsoon season (Bhatla et al. 2016).

As the decadal variation of the PDO and the number of Monsoon depression over the Bay of Bengal depicts a strong negative correlation. For instance, Several recent studies have shown that variability in the Pacific Ocean can modulate the Walker circulation over the Indo-Pacific basin, with subsidence over the Maritime continents and generate low-level easterly anomalies over the equatorial Indian Ocean (Krishnamurthy and Krishnamurthy 2014; Roxy et al. 2014).

The relationship of first modes of precipitation variability with the large-scale variability over two regions of Sri-Lanka is assessed and presented in Fig. 9. Three different sea surface temperature indices (SSTs) are utilized, within, which there is the oceanic Nino index (Nino3.4), refers to as sea surface
Table 1 The change point of the PC1 time series of SPEI-4 August, SPEI-6 at March, and seasonal rainfall during the Yala and Maha seasons. The letters "a," and "b," indicate the statistically significant step-change at $95 \%$, and $99 \%$ confidence levels, respectively

\begin{tabular}{|c|c|c|c|c|}
\hline \multirow[t]{2}{*}{ Method } & \multicolumn{2}{|l|}{ Yala season } & \multicolumn{2}{|l|}{ Maha season } \\
\hline & PC1-SPEI-4 & PC1-Rain & PC1-SPEI-6 & PC1-Rain \\
\hline CUSUM & $1999^{\mathrm{a}}$ & $1999^{\mathrm{a}}$ & 2002 & 1996 \\
\hline Cumulative deviation & $1999^{b}$ & $1999^{\mathrm{a}}$ & 2003 & 1996 \\
\hline Worsley likelihood & $1999^{\mathrm{a}}$ & $1999^{\mathrm{a}}$ & 2003 & $1996^{\mathrm{a}}$ \\
\hline
\end{tabular}



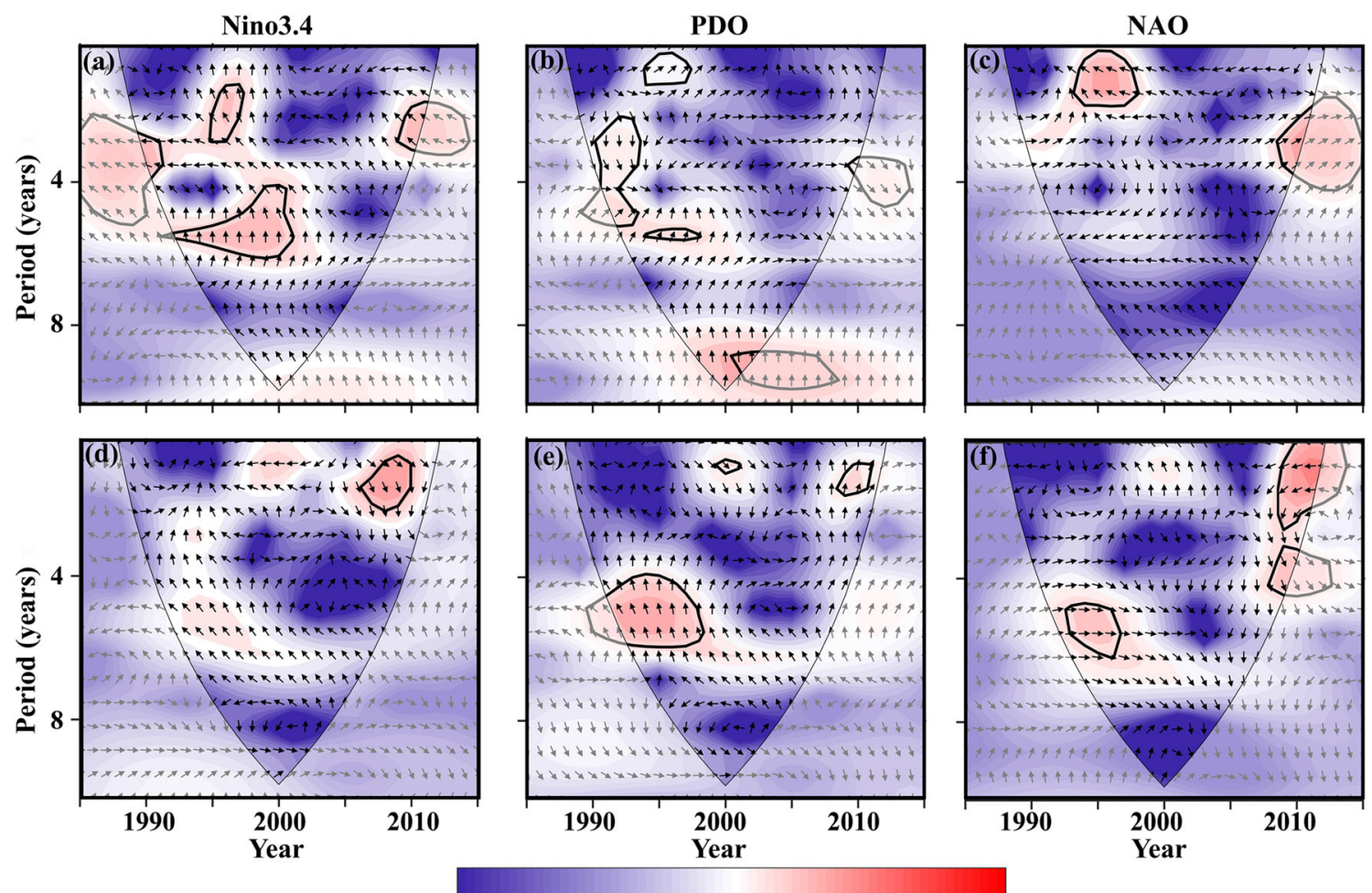

$\begin{array}{lll}1 / 8 & 1 / 4 & 1 / 2\end{array}$

Fig. 9 Cross wavelet transform of the rainfall PC1 time series with (a) Nino3.4, (b) Pacific decadal oscillation (PDO), and (c) North Atlantic oscillation (NAO) for the Yala season. A thick black contour line indicates a 95\% confidence level against the red noise. The arrows represent the relative phase relationship between the two-time series. $(\mathbf{d}-\mathbf{f})$, are the

same as the top panel, except for Maha season. Red (dark blue) color represents a higher variance in data. Arrows pointing upwards (downwards) indicate a lag (lead) of $90^{\circ}\left(-90^{\circ}\right)$ (one-quarter of a cycle), respectively. Arrows pointing to the left (right) indicate the antiphase (inphase) relationship, respectively

temperature anomalies in an area of the east-central equatorial Pacific Ocean, PDO and the NAO. A significant relationship between the NINO3.4 and PC1 of Yala rainfall (Fig. 9a) can be found within a 3-4-year, 2-3-year, 4-6-year, and 2-3-year bands oscillation over 1989-1992, 1995-1997, 1992-2001, and 2009-2011 time intervals, respectively. The highest peak that corresponds to the band of the 4-6-year is obtained for the period from 1992 to 2001 in the Yala season. The dominated arrows in this band are straight up, meaning that the Nino3.4 leads the rainfall by $90^{\circ}$. This signifies that nino3.4 influences the highest mode of precipitation variability over the area at different time scales ranging from 2 to 6 years. At this time, bands remain shows dominated out-of-phase variations between these parameters. A band of 2-3-year shows a significant relationship between the PC1 and Nino3.4 during 2006-2009 (Fig. 9d). This implies that the rainfall change over Maha is associated with the Nino3.4 anomaly. An in-phase variation between the rainfall and Nino3.4 is obtained over this area. It means that the positive (negative) face of Nino3.4 corresponds with a positive (negative) face of rainfall.

The PDO associated with the Yala rainfall variability depicts significant association coefficients during 1994-1997 corresponding to bands of 1-2-year and 5-6-year oscillations (Fig. 9b). Over the 1990-1993, 2009-2010, and 2000-2003 time intervals, 2-4-year, 10-12-year, and 3-4-year bands are attained. There is an overlapping band of the 4-5-year band between 1990 and 1993. Arrows within the band 2-4-year are straight down, whereas within 10-12-year are straight up, signifying that the Yala rainfall lags the PDO, but the latter leads the rainfall during the corresponding times. Bands remain to exhibit in-phase oscillations within their respective time. It means that the seas surface temperature anomaly influences the rainfall variability during the Yala season. Two important bands can be observed from the relationship between the rainfall during the Maha season and the PDO (Fig. 9e). These bands of 1-2-year and 4-6-year oscillations are found during 20082011 and 1991-1998, respectively. Anti-phase (in-phase) variation can be found over the band of 4-6-year (1-2-year), correspondingly. This means that a positive (negative) face of PDO is connected with a negative (positive) face of the rainfall.

Correlations between $\mathrm{PC} 1$ of rainfall in Yala season and NAO are significant over 1-2-year and 2-4-year bands during the period from 1993 to 1998 and from 2009 to 2011, respectively (Fig. 9c). It means that the NAO influences the rainfall variability over this region. Opposite flows can be observed between the NAO and PC1 in the Yala season during 19931998, meaning that positive variability in rainfall is linked with negative variability in NAO in this period. However, 
from 2009 to 2011, an in-phase oscillation between the two variables is apparent. This means the positive (negative) face of NAO matches with the positive (negative) face of rainfall. Significant relationships of the precipitation variability in Maha season are found in bands of 4-6-year and 1-4-year over 1993-1996 and 2008-2012, respectively (Fig. 9f). It means that the change in sea surface temperature over the NAO region is importantly associated with the high rainfall variability of the region. An in-phase relationship is obtained between the precipitation variability and the NAO during 1993-1996, whereas and dominant antiphase is acquired between these variables from 2008 to 2012. This means the positive (negative) face of NAO matches with a negative (positive) face of rainfall.

The SST variability through the teleconnection can lead to variations in geopotential height. The variability in geopotential height induces the variation in rainfall. Likewise, the moisture from SST could be transported via the circulation of the winds into the inland of Sri Lanka. Under certain boundary layer conditions, the moisture from the seas could undergo rising motions favoring (disturbing) the convection systems. This situation could lead to rainfall variability following the influence of sea surface temperature changes.

\subsection{Mechanism for Decadal Rainfall Shift for Yala Cropping Season}

Analysis of the moisture divergence variability provides insights into the major modes of precipitation variability, as well as the moisture sources themselves (Xu et al. 2016). Therefore, the EOF analysis was applied over the domain $5.5^{\circ} \sim 10^{\circ} \mathrm{N}$ and $79^{\circ} \mathrm{E} \sim 83^{\circ} \mathrm{E}$ to examine the spatial and temporal behavior of moisture flux divergence in the Yala season. Figure 9a and c illustrate the dominant mode of EOFs of Vertically Integrated Moisture Flux Divergence (VIMFD) during the Yala season, while the first (EOF1) and second (EOF2) modes account for $50 \%$ and $12 \%$ of the total variance, respectively. The first EOF captures extreme moisture divergence (convergence) patterns during the weak (strong) monsoon years, while deep moisture divergence (convergence) is located in the western/ southwestern parts of Sri Lanka. More than average moisture is converged when the $\mathrm{PC}$ of the year is positive (Fig. 9a). Furthermore, the 9-year running mean exhibits a decadal variation of PC1 time series, as shown in Fig. 9b. Based on Figs. 10a, b, the strongest moisture convergence is observed during 1985-1999, while moisture divergence over Sri Lanka is dominant during 2000-2015, which
Fig. 10 The (a) first EOF with explained variance $(\%)$ of mean vertically integrated moisture flux divergence (units;

$10^{-6} \mathrm{~kg} \mathrm{~m}^{-2} \mathrm{~s}^{-1}$ ) in the Yala season for 1985-2015 and (b) the corresponding principal component (PC1) time series. The lower panel is the same as the top panel, but for the second EOF and PC2. The 9 -year running mean of the PC time series is depicted in the black line. Positive and negative $\mathrm{PC} 1$ values are shown in blue and red colors, respectively. The wet, int, and dry represent the three climate regions

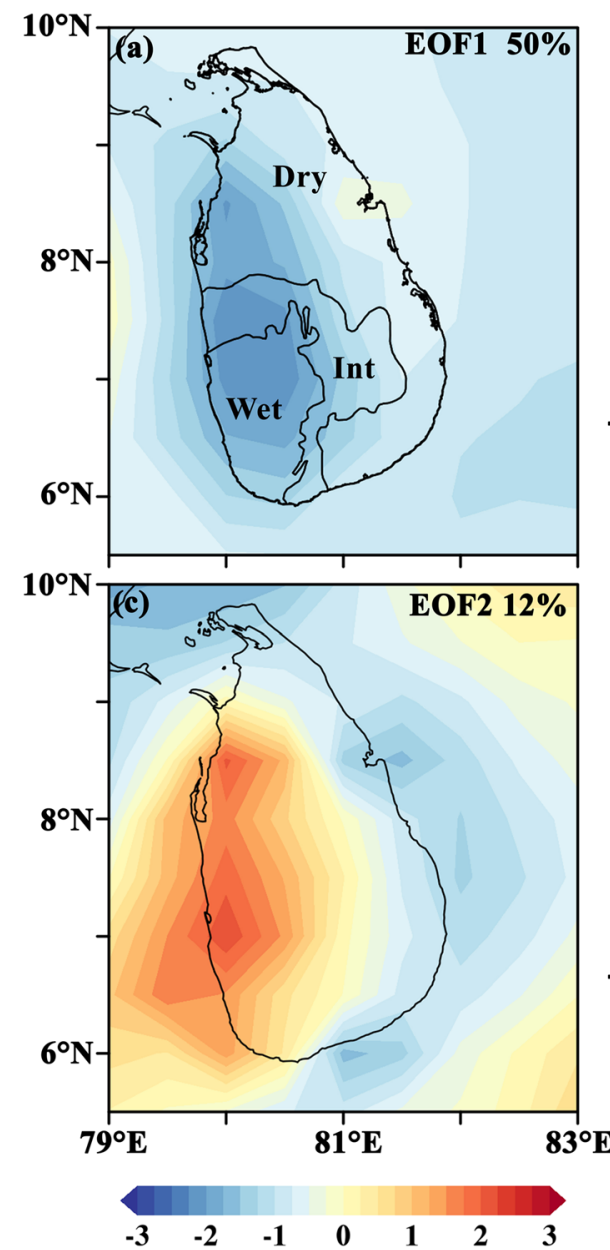

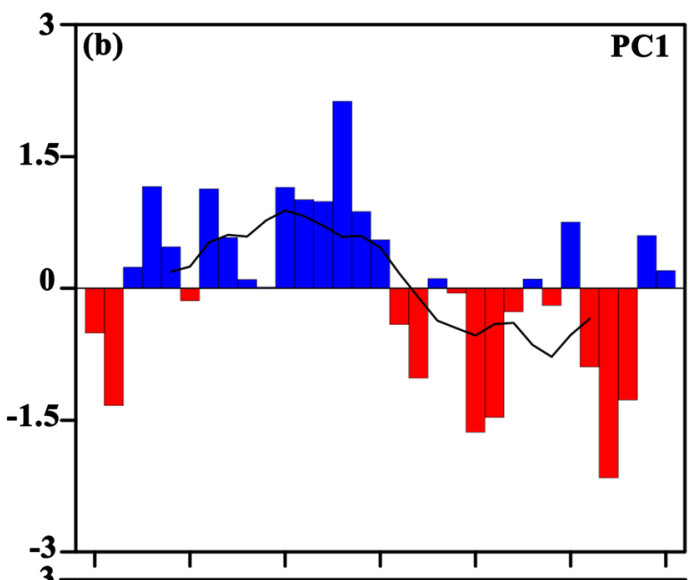

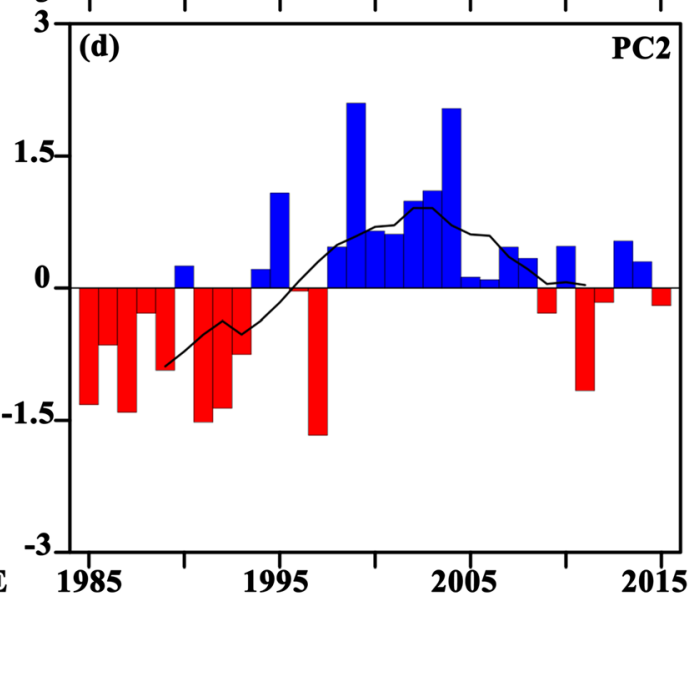


ascribed the observed decadal variation of Yala rainfall over Sri Lanka.

The second spatial pattern (Fig. 10c) portrays the most typical characteristics of the moisture flux divergence with uniformly negative (positive) departures located in the eastern and southeastern (western and southwestern) parts of the country. The time coefficient (Fig. 9d) shows more moisture divergence occurrences during the 1995-2007 period over the western /southwestern part of the country. A similar result has been recorded by $\mathrm{Xu}$ et al. (2016). They point out that the characterization of spatial patterns of inter-annual variability in the atmospheric moisture divergence over the tropical Pacific (EOF analyses) is linked directly to anomalies in rainfall.

In order to understand the decadal variation of VIMD over Sri Lanka during 1985-2015, We further investigate low-level wind (at $850 \mathrm{hPa}$ ) circulation and the difference between wet and dry years of the geopotential height. Figure 11 illustrates the mean state of wind circulation at $850 \mathrm{hPa}$. As a result of

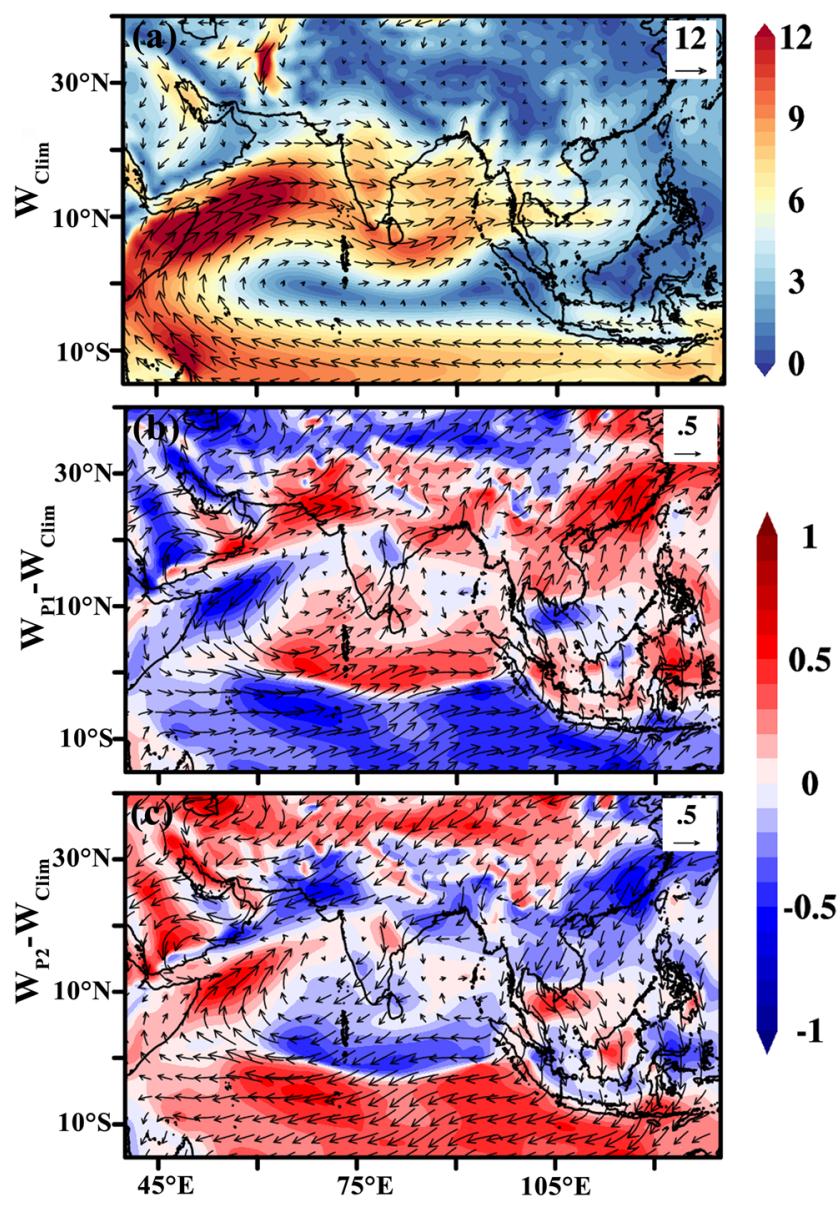

Fig. 11 The wind magnitude (shaded; $\mathrm{ms}^{-\mathbf{1}}$ ) at $850 \mathrm{hPa}$ superimposed with wind vectors in the Yala season averaged for (a) 1985-2015 $\left(\mathrm{W}_{\mathrm{Clim}}\right)$. (b, c) the same as (a) but for the anomalous wind for 1985$1999\left(\mathrm{~W}_{\mathrm{P} 1}\right)$ and 2000-2015 ( $\left.\mathrm{W}_{\mathrm{P} 2}\right)$, respectively. The reference wind vector magnitude is $12 \mathrm{~ms}^{-1}$ for the first panel and $0.5 \mathrm{~ms}^{-1}$ for the last two panels intensified surface evaporation due to the increase in wind speed over warm SSTs regions, releasing more heat flux in a strong wind environment. Chelton and Xie (2010) addressed that the releasing of strong heat flux strengthens atmospheric instability, which leads to strong convection over the region. As shown in Fig. 11a, the wind speed over the western and southwestern parts of Sri Lanka and the surrounding sea is greater than the Bay of Bengal's direction. In addition, it further shows that wind from the Arabian Sea direction brings moisture towards Sri Lanka. The wind magnitude of the early period (1985-1999) is strengthened compared to the longterm mean (Fig. 11b), while cyclonic wind circulation is observed near Sri Lanka and the eastern Arabian Sea. Pathak et al. (2017) identified that major atmospheric moisture contributors are the Western Indian Ocean (WIO), Central Indian Ocean (CIO), and Upper Indian Ocean (UIO) for the Indian summer monsoon period. Similarly, we found that the Arabian Sea (western Indian Ocean) is a key moisture source for the rainfall during the Yala season in Sri Lanka.

It also displays that the wind magnitude and wind direction in the late period are weaker than the long-term mean wind speed (Fig. 11c). This observed weakening of the monsoonal winds is caused by decreasing the land-sea thermal contrast because of warmer Arabian SST. Based on Fig. 10, we suggest that moisture convergence over Sri Lanka, especially over the wet region, is below normal for 2000-2015 that causes rainfall subsidence during the Yala season. Similarly, Izumo et al. (2008)found that a decrease in southwesterly winds would lead to a weaker monsoon rainfall by decreasing moisture convergence over the Indian summer monsoon region.

As observed, the weakening of the low-level jets is one of the key evidence for weakening the Yala rainfall over Sri Lanka for 2000-2015. In parallel with the observed result, Roxy et al. (2015) revealed that the weakening of mean southwesterly winds is one reason for the reduced Indian summer monsoon rainfall in recent decades. Lin et al. (2016) observed the decadal weakening of low-level south wind averaged over $110^{\circ} \mathrm{E} \sim 120^{\circ} \mathrm{E}$ due to East Asian summer monsoon in the late 1970s.

The geopotential height at $500 \mathrm{hPa}$ level (hereafter H500) in early (1985-1999) and late (2000-2015) periods is analyzed to identify the mechanism for the observed decadal changes of Yala rainfall. Figure 12a-b depicts the anomalous H500 averaged over two periods separately. As we know, the weak geopotential height anomaly creates a favorable condition for wind penetration over the continent. In the early period, H500 over most parts of the South Asian region, with large negative anomalies centered over Sri Lanka and the surrounding Indian Ocean. Positive H500 anomalies are located from the northern Arabian Sea to central Asia (i.e., between $45^{\circ} \mathrm{E}$ and $75^{\circ} \mathrm{E}$ ). Because of low H500, enhanced wind circulation brought considerable moisture towards the country in the early 
period and received above-average rainfall during the Yala season (Fig. 12a). Similar to these findings, Okoro et al. (2019) found that the $700 \mathrm{hPa}$ geopotential height has mainly negative (positive) anomalies in wet (dry) years at the Gulf of Guinea area and the eastern equatorial Atlantic.

Besides, increased geopotential heights and decreased frequency of depressions may have been related to increased frequencies and intensities of dry conditions (Türkeş 1998). The H500 anomalies in the late period are opposite to those in the early period. The positive H500 anomalies centered over Sri Lanka and surrounding areas can induce anomalous downward motion, which is favorable for deficient rainfall conditions (Fig. 12b). In general, the interdecadal difference of geopotential height anomalies is also consistent with the decadal change of rainfall anomalies during the Yala season in Sri Lanka, whereby more frequent and severe drought events occurred over the period from 2000 to 2015.

\section{Conclusion}

A comprehensive understanding of drought variation and its associated mechanisms are vital for the enhancement of drought mitigation planning. Therefore, the spatial and temporal characteristics of drought and the differential influence of ENSO, PDO, and NAO events on the drought over Sri Lanka have been examined for the two major cropping seasons. For this purpose, the multi-scale Standardized Precipitation Evapotranspiration Index (SPEI) was calculated for wet, intermediate, and dry climate zones in Sri Lanka during the period $1985-2015$. SPEI- $4_{\text {August }}$ and SPEI- $6_{\text {March }}$ were selected to evaluate drought variation during the Yala and Maha cropping seasons, respectively.

The SPEI- $6_{\text {March }}$ depicts more wet events after 2003, whereas from 1980 to 1999 , drought events are dominated. During the Maha season, this wetting tendency is favorable for agriculture and livestock productions, especially over the intermediate and dry regions. In Sri Lanka, the drought in the Yala season (SPEI-4 $4_{\text {August }}$ ) shows the decadal variation inherited by the decadal variation of the rainfall received during the Yala season. It also showed a step-change in 1999 and more drought events during the late period (2000-2015). We found that the SPEI-4 $4_{\text {August }}$ and SPEI- $6_{\text {March }}$ were closely associated with Southwest monsoon and northeast monsoon rainfall, respectively, over the three climate regions. Interestingly, the observed decadal variation of SPEI- $4_{\text {August }}$ can be ascribed by the decadal variation of rainfall in the Yala season.

We further investigate the causes for decadal variation in Yala rainfall and found that the moisture divergence also depicted a decadal shift compatible with the decadal weakening of Yala rainfall. It is well established that low-level moisture transport is a key contributor to the Indian summer monsoon rainfall. In terms of moisture transport, the low-level
Fig. 12 Anomalous geopotential height at $500 \mathrm{hPa}(\mathrm{H} 500)$ in Yala season averaged for the period of (a) 1985-1999 $\left(\mathrm{P}_{1}\right)$, and (b) 2000-2015 ( $\left.\mathrm{P}_{2}\right)$ periods. The climatology of $\mathrm{H} 500\left(\mathrm{H}_{500} \mathrm{Clim}\right)$ is calculated for the 1985-2015 period
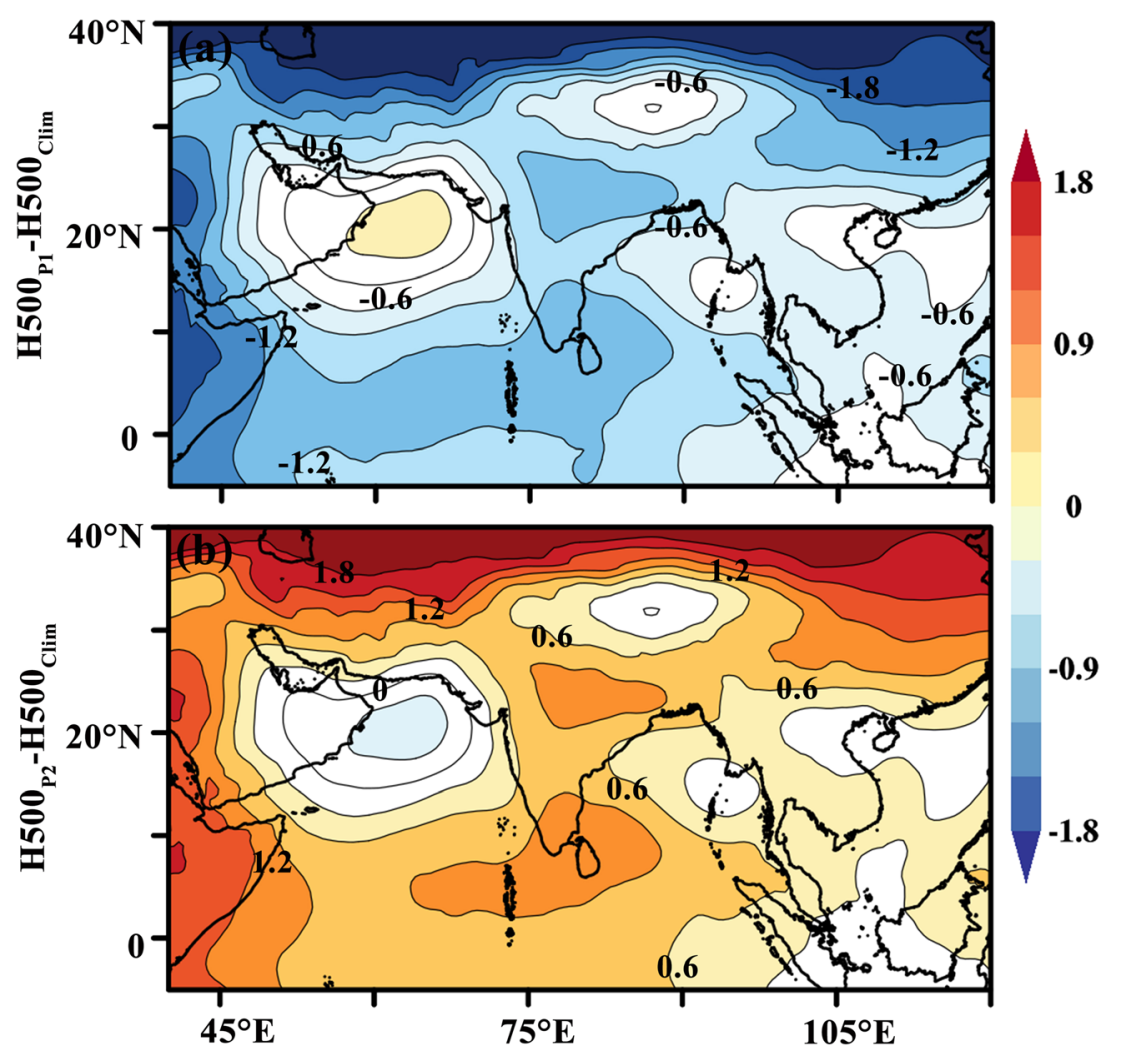

Korean Meteorological Society Springer 
wind circulation $(850 \mathrm{hPa})$ is studied in this study. Notably, the weakening of the $850 \mathrm{hPa}$ wind circulation in the late period (2000-2015) suppressed moisture transport and associated moisture convergence over Sri Lanka. Meanwhile, increasing the geopotential height at $500 \mathrm{hPa}$ reduces the winddriven moisture flux in the late period. On the other hand, the large-scale circulation characterizes the observed seasonal rainfall variability at interannual (Nino3.4) to decadal-scale (PDO, AMO).

It is stongly suggested that more complicated PET calculation method, such as FAO-56 Penman-Monteith (Valiantzas 2013), is applied to incoperate other climate variables except temperature, especially for the further projections of drought changes in the region.

This study provides valuable information for sustainable water resources management and agricultural activities across Sri Lanka. In addition, it allows taking adaptation measures to future climate changes by considering the widespread droughts anticipated in the coming decades that are important on a national scale. The lesson learned from previous drought experiences should be considered to set the adaptation strategies for future droughts.

Acknowledgments We are thankful to the Meteorological Department of Sri Lanka for providing weather data. The first author acknowledges the CAS-TWAS President's Fellowship Program for International Ph.D. student, China-Sri Lanka joint Center for Education and Research (CSLCER), Industrial Technology Institute-Sri Lanka.

\section{Declarations}

Conflict of Interest No potential conflict of interest was reported by the authors.

\section{References}

Aadhar, S., Mishra, V.: High-resolution near real-time drought monitoring in South Asia. Sci. Data. 4, 170145-170159 (2017). https://doi. org/10.1038/sdata.2017.145

Abiy, A.Z., Melesse, A.M., Seyoum, W.M., Abtew, W.: Chapter 22 drought and climate teleconnection and drought monitoring. In: Melesse, A.M., Abtew, W., Senay, G. (eds.) Extreme Hydrology and Climate Variability, pp. 275-295. Elsevier (2019)

Allen, K.J., Ogden, J., Buckley, B.M., Cook, E.R., Baker, P.J.: The potential to reconstruct broadscale climate indices associated with southeast Australian droughts from Athrotaxis species, Tasmania. Clim. Dyn. 37(9), 1799-1821 (2011). https://doi.org/10.1007/ s00382-011-1011-7

Back, L., Russ, K., Liu, Z., Inoue, K., Zhang, J., Otto-Bliesner, B.: Global hydrological cycle response to rapid and slow global warming. J. Clim. 26(22), 8781-8786 (2013). https://doi.org/10.1175/jcli-d-1300118.1

Bärring, L., Holt, T., Linderson, M.-L., Radziejewski, M., Moriondo, M., Palutikof, J.: Defining dry/wet spells for point observations, observed area averages, and regional climate model gridboxes in
Europe. Clim. Res. 31, 35-49 (2006). https://doi.org/10.3354/ cr031035

Beguería, S., Vicente-Serrano, S.M., Reig, F., Latorre, B.: Standardized precipitation evapotranspiration index (SPEI) revisited: parameter fitting, evapotranspiration models, tools, datasets and drought monitoring. Int. J. Climatol. 34(10), 3001-3023 (2014). https://doi.org/ $10.1002 /$ joc. 3887

Bhatla, R., Singh, A.K., Mandal, B., Ghosh, S., Pandey, S.N., Sarkar, A.: Influence of North Atlantic oscillation on Indian summer monsoon rainfall in relation to quasi-Binneal oscillation. Pure Appl. Geophys. 173(8), 2959-2970 (2016). https://doi.org/10.1007/s00024-016$1306-\mathrm{Z}$

Burchfield, E.K., Gilligan, J.: Agricultural adaptation to drought in the Sri Lankan dry zone. Appl Geogr 77, 92-100 (2016). https://doi.org/10. 1016/j.apgeog.2016.10.003

Burt, T.P., Weerasinghe, K.D.N.: Rainfall distributions in Sri Lanka in time and space: an analysis based on daily rainfall data. Climate. 2(4), 242-263 (2014). https://doi.org/10.3390/cli2040242

CentralBank: Annual Reports. https://www.cbsl.gov.lk/en/publications/ economic-and-financial-reports/annual-reports (2017). Accessed June 102017

Chelton, D., Xie, S.-P.: Coupled ocean-atmosphere interaction at oceanic mesoscales. Oceanography. 23, 52 (2010). https://doi.org/10.5670/ oceanog. 2010.05

Dai, A.: Drought under global warming: a review. Wiley Interdiscip. Rev. Clim. Chang. 2(1), 45-65 (2011). https://doi.org/10.1002/wcc.81

Dee, D.P., Uppala, S.M., Simmons, A.J., Berrisford, P., Poli, P., Kobayashi, S., Andrae, U., Balmaseda, M.A., Balsamo, G., Bauer, P., Bechtold, P., Beljaars, A.C.M., van de Berg, L., Bidlot, J., Bormann, N., Delsol, C., Dragani, R., Fuentes, M., Geer, A.J., Haimberger, L., Healy, S.B., Hersbach, H., Hólm, E.V., Isaksen, L., Kållberg, P., Köhler, M., Matricardi, M., McNally, A.P., Monge-Sanz, B.M., Morcrette, J.J., Park, B.K., Peubey, C., de Rosnay, P., Tavolato, C., Thépaut, J.N., Vitart, F.: The ERAInterim reanalysis: configuration and performance of the data assimilation system. Q. J. R. Meteorol. Soc. 137(656), 553-597 (2011). https://doi.org/10.1002/qj.828

Deng, S., Chen, T., Yang, N., Qu, L., Li, M., Chen, D.: Spatial and temporal distribution of rainfall and drought characteristics across the Pearl River basin. Sci. Total Environ. 619-620, 28-41 (2018). https://doi.org/10.1016/j.scitotenv.2017.10.339

Echer, M.P.S., Echer, E., Nordemann, D.J., Rigozo, N.R., Prestes, A.: Wavelet analysis of a centennial (1895-1994) southern Brazil rainfall series (Pelotas, $\left.31^{\circ} 46^{\prime} 19^{\prime \prime} \mathrm{S} 52^{\circ} 20^{\prime} 33^{\prime \prime} \mathrm{W}\right)$. Clim. Chang. 87(3), 489-497 (2008). https://doi.org/10.1007/s10584-007-9296-6

FAO: The impact of natural hazards and disasters on agriculture and food and nutrition security. In: Food and Agriculture Organization of the United Nations, Rome (2015)

FAO: 2017 The impact of disasters and crises on agriculture and food security. In: Food and Agriculture Organization of the United Nations, Rome, (2018)

Gocic, M., Trajkovic, S.: Analysis of precipitation and drought data in Serbia over the period 1980-2010. J. Hydrol. 494, 32-42 (2013). https://doi.org/10.1016/j.jhydrol.2013.04.044

Grinsted, A., Moore, J.C., Jevrejeva, S.: Application of the cross wavelet transform and wavelet coherence to geophysical time series. Nonlin. Process. Geophys. 11(5/6), 561-566 (2004). https://doi.org/10. 5194/npg-11-561-2004

Gunda, T., M., H.G., M., G.J.: Spatiotemporal Patterns of Agricultural Drought in Sri Lanka: 1881-2010. Int J Climatol 36(2), 563-575 (2016). https://doi.org/10.1002/joc.4365

Han, D., Bray, M.: Automated Thiessen polygon generation. Water Resour. Res. 42(11), 37 (2006). https://doi.org/10.1029/ $2005 \mathrm{wr} 004365$

Hannachi, A., Jolliffe, I.T., Stephenson, D.B.: Empirical orthogonal functions and related techniques in atmospheric science: a review. Int. J. 
Climatol. 27(9), 1119-1152 (2007). https://doi.org/10.1002/joc. 1499

IPCC: In: Barros, V.R., Field, C.B., Dokken, D.J., Mastrandrea, M.D., Mach, K.J., Bilir, T.E., Chatterjee, M., Ebi, K.L., Estrada, Y.O., Genova, R.C., Girma, B., Kissel, E.S., Levy, A.N., MacCracken, S., Mastrandrea, P.R., White, L.L. (eds.) Climate Change 2014: Impacts, Adaptation, and Vulnerability. Part B: Regional Aspects. Contribution of Working Group II to the Fifth Assessment Report of the Intergovernmental Panel on Climate Change. Cambridge University Press, Cambridge, UK (2014)

Izumo, T., Montégut, C.B., Luo, J.-J., Behera, S.K., Masson, S., Yamagata, T.: The role of the Western Arabian Sea upwelling in Indian monsoon rainfall variability. J. Clim. 21(21), 5603-5623 (2008). https://doi.org/10.1175/2008jcli2158.1

Jayawardene, H.K.W.I., Sonnadara, U., Jayewardene, R.: Trends of rainfall in Sri Lanka over the last century. Sri Lankan J. Phys. 6, 7-17 (2005). https://doi.org/10.4038/sljp.v6i0.197

Kim, D.H., Yoo, C., Kim, T.-W.: Application of spatial EOF and multivariate time series model for evaluating agricultural drought vulnerability in Korea. Adv. Water Resour. 34(3), 340-350 (2011). https:// doi.org/10.1016/j.advwatres.2010.12.010

Kripalani, R.H., Kulkarni, A.: Climatology and variability of historical soviet snow depth data: some new perspectives in snow - Indian monsoon teleconnections. Clim. Dyn. 15(6), 475-489 (1999). https://doi.org/10.1007/s003820050294

Krishnamurthy, L., Krishnamurthy, V.: Influence of PDO on South Asian summer monsoon and monsoon-ENSO relation. Clim Dyn 42, 2397 (2014). https://doi.org/10.1007/s00382-013-1856-z

Lesk, C., Rowhani, P., Ramankutty, N.: Influence of extreme weather disasters on global crop production. Nature. 529, 84-87 (2016). https://doi.org/10.1038/nature16467

Lin, Z., Shelton, S.: Interdecadal change of drought characteristics in Mahaweli River basin of Sri Lanka and the associated atmospheric circulation difference. Front. Earth Sci. 8, 306-324 (2020). https:// doi.org/10.3389/feart.2020.00306

Lin, R., Zhu, J., Zheng, F.: Decadal shifts of east Asian summer monsoon in a climate model free of explicit GHGs and aerosols. Sci. Rep. 6(1), 38546 (2016). https://doi.org/10.1038/srep38546

Lyon, B., Zubair, L., Ralapanawe, V., Yahiya, Z.: Finescale Evaluation of Drought in a Tropical Setting: Case Study in Sri Lanka. J Appl Meteorol Climatol 48(1), 77-88 (2009). https://doi.org/10.1175/ 2008JAMC1767X.1

Malmgren, B.A., Hulugalla, R., Hayashi, Y., Mikami, T.: Precipitation trends in Sri Lanka since the 1870s and relationships to El Niñosouthern oscillation. Int. J. Climatol. 23(10), 1235-1252 (2003). https://doi.org/10.1002/joc.921

Marambe, B., Punyawardena, R., Silva, P., Premalal, S., Rathnabharathie, V., Kekulandala, B., Nidumolu, U., Howden, M.: Climate, Climate Risk, and Food Security in Sri Lanka: Need for Strengthening Adaptation Strategies. In: Leal Filho, W. (ed.) Handbook of Climate Change Adaptation. pp. 1-27. Springer Berlin Heidelberg, Berlin, Heidelberg (2014)

Mavromatis, T.: Drought index evaluation for assessing future wheat production in Greece. Int. J. Climatol. 27(7), 911-924 (2007). https://doi.org/10.1002/joc. 1444

McKee, T.B., Doesken, N.J., Kleist, J.: The relationship of drought frequency and duration to time scale. In: Proceedings of the Eighth Conference on Applied Climatology, Anaheim, CA, USA, 17-22 January (1993)

Navarra, A., Simoncini, V.: A Guide to Empirical Orthogonal Functions for Climate Data Analysis. In: pp. 25-37. (2010)

Niranjan Kumar, K., Rajeevan, M., Pai, D.S., Srivastava, A.K., Preethi, B.: On the observed variability of monsoon droughts over India. Weather Clim. Extremes. 1, $42-50$ (2013). https://doi.org/10.1016/ j.wace.2013.07.006
O'Gorman, P.A.: Sensitivity of tropical precipitation extremes to climate change. Nat. Geosci. 5, 697-700 (2012). https://doi.org/10.1038/ ngeo 1568

Okoro, U.K., Chen, W., Nath, D.: Recent variations in geopotential height associated with west African monsoon variability. Meteorog. Atmos. Phys. 131(3), 553-565 (2019). https://doi.org/ 10.1007/s00703-018-0593-6

Palmer, W.C.: Meteorologic Drought Research Paper No. 45, p. 58. US Department of Commerce,Weather Bureau, Washington, DC (1965)

Pathak, A., Ghosh, S., Kumar, P., Murtugudde, R.: Role of oceanic and terrestrial atmospheric moisture sources in Intraseasonal variability of Indian summer monsoon rainfall. Sci. Rep. 7(1), 12729 (2017). https://doi.org/10.1038/s41598-017-13115-7

Polade, S., Pierce, D., Cayan, D., Gershunov, A., Dettinger, M.: The key role of dry days in changing regional climate and precipitation regimes. Sci. Rep. 4, 4364 (2014). https://doi.org/10.1038/srep04364

Potop, V., Možný, M., Soukup, J.: Drought evolution at various time scales in the lowland regions and their impact on vegetable crops in the Czech Republic. Agric. For. Meteorol. 156, 121-133 (2012). https://doi.org/10.1016/j.agrformet.2012.01.002

Potopová, V., Štěpánek, P., Možný, M., Türkott, L., Soukup, J.: Performance of the standardised precipitation evapotranspiration index at various lags for agricultural drought risk assessment in the Czech Republic. Agric. For. Meteorol. 202, 26-38 (2015). https:// doi.org/10.1016/j.agrformet.2014.11.022

Quiring, S.M.: Monitoring drought: an evaluation of meteorological drought indices. Geogr. Compass. 3(1), 64-88 (2009). https://doi. org/10.1111/j.1749-8198.2008.00207.X

Ranatunge, E., Malmgren, B.A., Hayashi, Y., Mikami, T., Morishima, W., Yokozawa, M., Nishimori, M.: Changes in the southwest monsoon mean daily rainfall intensity in Sri Lanka: relationship to the El Nino-southern oscillation. Palaeogeogr. Palaeocl. 197(1-2), 1-14 (2003). https://doi.org/10.1016/S0031-0182(03)00383-3

Rayner, N.A., Parker, D., Horton, E.B., Folland, C., Alexander, L., Rowell, D., Kent, E., Kaplan, A.: Global analyses of sea surface temperature, sea ice, and night marine air temperature since the late nineteenth century. J. Geophys. Res. 108(2003), 4407 (2003). https://doi.org/10.1029/2002JD002670

Rosmann, T., Domínguez, E., Chavarro, J.: Comparing trends in hydrometeorological average and extreme data sets around the world at different time scales. J. Hydrol. Reg. Stud. 5, 200-212 (2016). https://doi.org/10.1016/j.ejrh.2015.12.061

Roxy, M.K., Ritika, K., Terray, P., Murtugudde, R., Ashok, K., Goswami, B.N.: Drying of Indian subcontinent by rapid Indian Ocean warming and a weakening land-sea thermal gradient. Nat. Commun. 6, 7423-7427 (2015). https://doi.org/10.1038/ ncomms 8423

Roxy, M.K., Ritika, K., Terray, P., Masson, S.: The Curious Case of Indian Ocean Warming. J Clim 27(22), 8501-8509 (2014). https:// doi.org/10.1175/jcli-d-14-00471.1

Rubasinghe, R., Gunatilake, S.K., Chandrajith, R.: Geochemical characteristics of groundwater in different climatic zones of Sri Lanka. Environ. Earth Sci. 74(4), 3067-3076 (2015). https://doi.org/10. 1007/s12665-015-4339-1

van der Schrier, G., Jones, P.D., Briffa, K.R.: The sensitivity of the PDSI to the Thornthwaite and Penman-Monteith parameterizations for potential evapotranspiration. J. Geophys. Res. Atmos. 116(D3), (2011). doi:https://doi.org/10.1029/2010jd015001

Schumann, A.H.: Thiessen polygon. In: Encyclopedia of Hydrology and Lakes. Encyclopedia of Earth Science. Springer, Dordrecht. (1998). https://doi.org/10.1007/1-4020-4497-6_220

Seager, R., Naik, N., Vogel, L.: Does global warming cause intensified interannual hydroclimate variability? J. Clim. 25(9), 3355-3372 (2012). https://doi.org/10.1175/jcli-d-11-00363.1 
Shaman, J., Tziperman, E.: Summertime ENSO-North African-Asian Jet teleconnection and implications for the Indian monsoons. Geophys. Res. Lett. 34(11), L11702 (2007). https://doi.org/10.1029/ 2006GL029143

Sheffield, J., Wood, E.F., Roderick, M.L.: Little change in global drought over the past 60 years. Nature 491, 435-438 (2012). https://doi.org/ 10.1038 /nature 11575

Sheffield, J., Wood, E.F.: Projected changes in drought occurrence under future global warming from multi-model, multi-scenario, IPCC AR4 simulations. Clim Dyn 31(1), 79-105 (2008). https://doi.org/ 10.1007/s00382-007-0340-Z

Shelton, S., Lin, Z.: Streamflow variability over the period of 1990-2014 in Mahaweli River basin, Sri Lanka and its possible mechanisms. Water. 11(12), 2485-2506 (2019). https://doi.org/10.3390/ w11122485

Sonnadara, D.U.J.: The onset, retreat and the length of growing season in the north-eastern region of Sri Lanka. Int. J. Climatol. 35(12), 36333639 (2015). https://doi.org/10.1002/joc.4237

Spinoni, J., Naumann, G., Vogt, J.V.: Pan-European seasonal trends and recent changes of drought frequency and severity. Glob. Planet. Chang. 148, 113-130 (2017). https://doi.org/10.1016/j.gloplacha. 2016.11.013

Sun, F., Roderick, M.L., Farquhar, G.D.: Changes in the variability of global land precipitation. Geophys. Res. Lett. 39(19), L19402 (2012). https://doi.org/10.1029/2012GL053369

Thornthwaite, C.W.: An approach toward a rational classification of climate. Geogr. Rev. 38(1), 55-94 (1948)

Torres-Valcárcel, A.R.: Teleconnections between ENSO and rainfall and drought in Puerto Rico. Int. J. Climatol. 38(S1), e1190-e1204 (2018). https://doi.org/10.1002/joc.5444

Tsakiris, G.: Meteorological drought assessment. In: Proceedings of the European Research Program MEDROPLAN (Mediterranean Drought Preparedness andMitigation Planning), Zaragoza, Spain 2 April 2004 (2004)

Türkeş, M.: Influence of geopotential heights, cyclone frequency and southern oscillation on rainfall variations in Turkey. Int. J. Climatol. 18(6), 649-680 (1998)

Valiantzas, J.D.: Simplified forms for the standardized FAO-56 PenmanMonteith reference evapotranspiration using limited weather data. J. Hydrol. 505, 13-23 (2013). https://doi.org/10.1016/j.jhydrol.2013. 09.005

Van Loon, A.F.: Hydrological drought explained. WIREs Water. 2(4), 359-392 (2015). https://doi.org/10.1002/wat2.1085

Vicente-Serrano, S.M., Beguería, S., López-Moreno, J.I.: A multiscalar drought index sensitive to global warming: the standardized precipitation evapotranspiration index. J. Clim. 23(7), 1696-1718 (2010). https://doi.org/10.1175/2009jcli2909.1

Vicente-Serrano, S.M., López-Moreno, J.I., Gimeno, L., Nieto, R., Morán-Tejeda, E., Lorenzo-Lacruz, J., Beguería, S., AzorinMolina, C.: A multiscalar global evaluation of the impact of ENSO on droughts. J. Geophys. Res. Atmos. 116(D20), (2011). doi: https://doi.org/10.1029/2011jd016039

Vicente-Serrano, S.M., Camarero, J.J., Olano, J.M., Martín-Hernández, N., Peña-Gallardo, M., Tomás-Burguera, M., Gazol, A., AzorinMolina, C., Bhuyan, U., El Kenawy, A.: Diverse relationships between forest growth and the normalized difference vegetation index at a global scale. Remote Sens. Environ. 187, 14-29 (2016). https:// doi.org/10.1016/j.rse.2016.10.001

Vicente-Serrano, S.M., McVicar, T.R., Miralles, D.G., Yang, Y., TomasBurguera, M.: Unraveling the influence of atmospheric evaporative demand on drought and its response to climate change. WIREs Clim. Chang. 11(2), e632 (2020). https://doi.org/10.1002/wcc.632

Wang, H., Chen, Y., Pan, Y., Li, W.: Spatial and temporal variability of drought in the arid region of China and its relationships to teleconnection indices. J. Hydrol. 523, 283-296 (2015). https://doi. org/10.1016/j.jhydrol.2015.01.055

Wang, Y., Zhang, J., Guo, E., Dong, Z., Quan, L.: Estimation of variability characteristics of regional drought during 1964-2013 in Horqin Sandy land, China. Water. 8(11), 543 (2016). https://doi.org/10. 3390/w8110543

Wang, S., Yuan, X., Li, Y.: Does a strong El Niño imply a higher predictability of extreme drought? Sci. Rep. 7, 40741 (2017). https:// doi.org/10.1038/srep40741

Wang, Y., Liu, G., Guo, E.: Spatial distribution and temporal variation of drought in Inner Mongolia during 1901-2014 using standardized precipitation evapotranspiration index. Sci. Total Environ. 654, 850-862 (2019). https://doi.org/10.1016/j.scitotenv.2018.10.425

Wickramagamage, P.: Spatial and temporal variation of rainfall trends of Sri Lanka. Theor. Appl. Climatol. 125(3), 427-438 (2016). https:// doi.org/10.1007/s00704-015-1492-0

Xiao, M., Zhang, Q., Singh, V.P.: Influences of ENSO, NAO, IOD and $\mathrm{PDO}$ on seasonal precipitation regimes in the Yangtze River basin, China. Int. J. Climatol. 35(12), 3556-3567 (2015). https://doi.org/ $10.1002 /$ joc. 4228

Xiao, M., Zhang, Q., Singh, V.P., Liu, L.: Transitional properties of droughts and related impacts of climate indices in the Pearl River basin, China. J. Hydrol. 534, 397-406 (2016). https://doi.org/10. 1016/j.jhydrol.2016.01.012

Xu, G., Osborn, T.J., Matthews, A.J., Joshi, M.M.: Different atmospheric moisture divergence responses to extreme and moderate El Niños. Clim. Dyn. 47(1), 393-410 (2016). https://doi.org/10.1007/s00382015-2844-2

Yao, J., Zhao, Y., Chen, Y., Yu, X., Zhang, R.: Multi-scale assessments of droughts: a case study in Xinjiang, China. Sci. Total Environ. 630, 444-452 (2018). https://doi.org/10.1016/j.scitotenv.2018.02. 200

Zhang, L., Zhou, T.: Drought over East Asia: a review. J. Clim. 28(8), 3375-3399 (2015). https://doi.org/10.1175/jcli-d-14-00259.1

Zhang, Y., Wallace, J.M., Battisti, D.S.: ENSO-like interdecadal variability: 1900-1993. J. Clim. 10(5), 1004-1020 (1997)

Zhao, D., Li, Y.-R.: Climate change and sugarcane production: potential impact and mitigation strategies. Int. J. Agron. 2015, 547386 547310 (2015). https://doi.org/10.1155/2015/547386

Zubair, L., Ralapanawe, V., Tennakone, U., Yahiya, Z., Perera, R.: Natural disaster risks in Sri Lanka: Mapping hazards and risk hotspot. In: M. Arnold et al., (eds.) Case Studies, pp. 109-136. World Bank (2006)

Publisher's Note Springer Nature remains neutral with regard to jurisdictional claims in published maps and institutional affiliations. 